\title{
Managerial Entrenchment and Corporate Social Performance
}

\author{
Jordi Surroca AND Josep A. Tribó*
}

\begin{abstract}
We examine empirically the relationships amongst managerial entrenchment practices, social performance, and financial performance. We hypothesize that entrenched managers may collude with non-shareholder stakeholders in order to reinforce their entrenchment strategy; this is particularly so in firms that have efficient internal control mechanisms. Moreover, we prove that the combination of entrenchment strategies and the implementation of socially responsible actions have particularly negative effects on financial performance. We test these contentions with a sample of 358 companies, from 22 different countries, for the period 20022005 .
\end{abstract}

Keywords: corporate governance, corporate social performance, earnings management, stakeholder activism

\section{INTRODUCTION}

Agency theory has contributed to reinforce the long held view that agency problems are at the core of conflicts that appear within organizations. The literature distinguishes between two main agency problems: the conflict between large and small shareholders, which generates minority expropriation issues (Shleifer and Vishny, 1986); and the conflict between managers and shareholders that drives managers to pursue their own private benefits at the expense of shareholder interests (Jensen and Meckling, 1976). The latter problem is exacerbated when managers are set on entrenchment:

\footnotetext{
* The authors are from the Universidad Carlos III de Madrid, Department of Business Administration. They wish to thank Carlos Bendito, Managing Director of Analistas Internacionales en Sostenibilidad (AISTM) a Sustainable Investment Research International Company partner firm based in Spain - for their helpful comments and access to the SiRi Pro ${ }^{\mathrm{TM}}$ database. They would also like to thank Martin Walker (editor), Diego Prior, Stathopoulos Konstantinos, Joan Santalo and one of the anonymous referees as well as participants at the JBFA Capital Markets Conference (Chapel Hill, 2007), the Academy of Management Annual Meeting (Philadelphia, 2007), the Symposium of Corporate Governance \& Shareholder Activism (Milan, 2007), the Journal of Banking and Finance $30^{\text {th }}$ Anniversary Conference (Beijing, 2006), the Strategic Management Conference (Vienna, 2006), the Foro de Finanzas (Castellon, 2006) and the seminar participants at Universitat Autònoma of Barcelona for their useful comments on earlier drafts of this paper. They also acknowledge the financial support of the Ministerio de Ciencia y Tecnologia (grant \#SEC2003-03797), Ministerio de Educación y Ciencia (grant \# SEJ2004-07877-C02-02 and grant \#SEJ2006-09401), and the Comunidad de Madrid (Grant \#s-0505/tic/000230). The usual disclaimers apply.
}

Address for correspondence: Josep A. Tribó, Universidad Carlos III de Madrid, Department of Business Administration, Calle Madrid, 126, Getafe (Madrid), Spain 28903.

e-mail: joatribo@emp.uc3m.es 
they attempt to neutralize the disciplinary mechanism of the capital market so as to maintain corporate control (Jensen and Ruback, 1983).

Managers, who place great value on control while holding only a small equity stake, work to ensure their own job security, even though they are no longer competent or qualified to run the firm (Shleifer and Vishny, 1989). Walsh and Seward (1990) discuss classes of managerial entrenchment practices. Dual-class recapitalization, poison pills, supermajority amendments, anti-takeover amendments, and golden parachutes are examples of such practices. Others (Morck et al., 1988; Stulz, 1988; and de Miguel et al., 2004) emphasize that managerial ownership above certain levels is a takeover deterrence mechanism that promotes managerial entrenchment. The use of these mechanisms decreases managerial turnover, which is taken as another proxy of managerial entrenchment (Denis et al., 1997; and Dahya et al., 1998). Finally, managers can resort to income smoothing and other earnings management practices as a way of improving their job security (Fudenberg and Tirole, 1995; and Yeo et al., 2002).

Although anti-takeover defenses may decrease the efficiency of external control mechanisms, they do not have the same effect on internal control mechanisms. Hence, in a context of well developed internal control mechanisms, a manager set on entrenchment has all the incentives to seek the connivance of non-shareholder stakeholders against the actions of shareholders. Along these lines, we continue the work of Cespa and Cestone (2007) and hypothesize that entrenched managers collude with employees, communities, customers, and suppliers to protect themselves from internal disciplining mechanisms, causing a subsequent reduction in shareholders' wealth. We rely on three arguments to justify the manager's commitment to follow stakeholder-friendly behavior, especially in those firms with efficient internal corporate governance mechanisms. First, stakeholders generally acquire certain powers to promote or penalize top executives (DeAngelo and DeAngelo, 1998; Hellwig, 2000; and Rowley and Berman, 2000); they can engage in costly boycotts and media campaigns (Baron, 2001; Feddersen and Gilligan, 2001; and John and Klein, 2003), and stakeholder representatives may be present on corporate boards (Luoma and Goodstein, 1999; and Schneper and Guillén, 2004). Moreover, due to the fact that the manager retains the confidence of stakeholders, it will be difficult for displeased shareholders to remove him because they would have to face pressure from the nonshareholder stakeholders.

The second argument which justifies stakeholder concessions for entrenchment purposes is that, by colluding with stakeholders, the manager reduces a firm's attractiveness to potential raiders. For example, generous long-term stakeholder concessions hinder the raider's ability to generate profit (Pagano and Volpin, 2005). Finally, we rely on Sundaramurthy et al. (1997) to justify the positive, moderating role of internal corporate control mechanisms that use stakeholder satisfaction as an entrenchment mechanism. These authors show that the efficacy of some entrenchment mechanisms, like anti-takeover measures, against external corporate governance mechanisms is moderated by internal corporate governance mechanisms like board configuration. We extend this result and argue that the moderating role of internal corporate control mechanisms also holds for other entrenchment mechanisms like stakeholder satisfaction.

In order to gain support from stakeholders, entrenched managers engage in a broad array of practices to develop relationships with corporate stakeholders and environmental activists; the so-called corporate social performance (CSP), as explained 
in Waddock (2004). This study specifically tests the hypothesis that managerial entrenchment practices are positively related to improvements in CSP which, in turn, negatively affect firms' financial performance. Moreover, we expect this relationship will be stronger in those firms with well-developed internal corporate governance mechanisms.

We make use of an international database provided by the Sustainable Investment Research International Company, an international network of social research organizations that scrutinizes firms with respect to their practices toward employees, communities, suppliers, customers, the environment, and shareholders. These data include and expand upon those of Kinder, Lyndemberg, Domini and Company (KLD). Our final sample comprises 358 firms from 22 nations.

Our study advances the understanding of stakeholder phenomena by providing evidence of another explanation for CSP: the entrenchment hypothesis (Cespa and Cestone, 2007). Also, this study augments agency theory from a stakeholder perspective, by examining the role employees, communities, customers, and suppliers, may play in exacerbating or ameliorating conflicts of interest between managers and shareholders. We expand the game-theoretical model of Pagano and Volpin (2005) to include not only workers but other stakeholders (Cespa and Cestone, 2007), and subsequently, we empirically test its main propositions. Finally, we provide evidence of the entrenchment motives that explain earnings manipulations like income smoothing (Fudenberg and Tirole, 1995; and Yeo et al., 2002) as well as their connection with CSP. Managers smooth earnings, as part of an entrenchment strategy, in order to ensure the stability of cash-flow streams so that they can satisfy the short-term interests of shareholders. However, this practice may generate problems in the medium term. Then, in order to eliminate possible medium-term problems that may put their jobs at risk, managers will try to connive with non-shareholder stakeholders by satisfying the interests of this group (improving a firm's CSP). Hence, regardless of the entrenchment mechanism used, we claim that entrenchment practices lead to improvements in a firm's CSP, particularly in the presence of strong internal corporate governance mechanisms.

The remainder of the paper is structured as follows. Section 2 summarizes the most relevant literature and develops the hypotheses. Section 3 is methodological and describes the sample, variables and empirical models to be tested. The empirical results obtained are presented in Section 4, while some extensions are addressed in Section 5. In the final section, we lay out the main conclusions of this research and discuss the significance of our results.

\section{THEORYAND HYPOTHESES}

Traditionally, agency theory has dominated the analysis of corporate governance. Its main concern is the separation of ownership and control which generates minority expropriation problems (Shleifer and Vishny, 1986) as well as problems between managers and firm owners (Jensen and Meckling, 1976). Focusing on managerial actions that damage shareholder interests, one of the costliest manifestations of these actions is managerial entrenchment; and this can take a variety of forms. Among them are: the issue of common stock with limited voting rights, exchanged for a certain number of original common shares; poison pills; new security issues; specific acquisitions and divestitures; supermajority amendments; golden parachutes; and earnings smoothing. Additionally, managers may try to accumulate stakes large enough 
to eliminate the threat of takeover but not too large in order to avoid incurring the internalization of entrenchment costs. Hence entrenchment is expected to be found in a middle range of managerial ownership (Morck et al., 1988; and de Miguel et al., 2004). This set of mechanisms defines an entrenchment strategy that could decrease managerial turnover (Denis et al., 1997; and Dahya et al., 1998).

Remarkably, these strategies are used principally by managers to deal with the pressure from external corporate control mechanisms, as defined by Shleifer and Vishny (1997). The market for corporate control, product market competition or managerial labor markets are examples of external mechanisms of corporate governance aimed at reducing the agency problems linked to managerial actions. However, there are other control mechanisms that are effective in preventing the aforementioned entrenchment practices, and are defined as internal (Shleifer and Vishny, 1997). Among these internal mechanisms are: stock-options and other forms of performance-based payment schemes; control structures such as the presence of institutional blockholders (Shleifer and Vishny, 1986); the presence of outsiders on the board of directors (Fama and Jensen, 1983); or the existence of committees for audit, remuneration and nomination control (Vafeas, 1999; and Anderson and Reeb, 2004).

Hence, those managers that even under the close scrutiny of internal corporate control mechanisms are set on entrenchment, need to reinforce their entrenchment strategy by adopting some additional initiatives. We augment the propositions from Cespa and Cestone (2007) and highlight stakeholder satisfaction as one of the initiatives achieved when internal corporate control mechanisms are well developed. Stakeholders wield significant power within the firm. They can organize boycotts and lobbies to demonstrate such power (Baron, 2001; Feddersen and Gilligan, 2001; and John and Klein, 2003). Further, stakeholders may exercise their influence via the board of directors, when the board includes representations from labor, creditors, and regulatory agencies (Schneper and Guillén, 2004). Under such a control structure, managerial decisions are monitored and influenced by the presence of stakeholder representatives (Luoma and Goodstein, 1999). Finally, the actions of stakeholders may influence the threat of a hostile takeover and with that their own CEO replacement. ${ }^{1}$ Then, when internal corporate governance mechanisms are well developed, managers tend to reinforce their entrenchment strategy by canvassing support from stakeholders so as to channel the efforts of the latter to the entrenched manager's own advantage. This strategy enjoys the benefit of diminishing pressure from activist stakeholders while at the same time countering the pressure from other internal corporate control mechanisms. To operationalize such behavior, managers may engage in practices to create and manage relationships with corporate stakeholders, the so-called CSP.

Our entrenchment argument for improving CSP is explained by the stakeholders' power to influence the firm. As such, our story belongs to the descriptive realm of stakeholder theory (Mitchell et al., 1997). According to this theory, the degree to which managers assign priority to competing stakeholders' claims - stakeholder salience is positively related to the cumulative number of stakeholder's attributes of power, legitimacy, and urgency. Thus, a manager who wants to implement an entrenchment

1 Schneper and Guillén (2004) show that the frequency of hostile takeovers is inversely related to stakeholders' (non-shareholder) power, and this result may explain why countries labeled as stakeholderoriented like Germany or Japan are characterized by the low occurrence of hostile takeovers. 
strategy will want to be protected against the actions of powerful stakeholders. In that case, there are two possibilities: collaboration or confrontation.

Jones (1995) and Hill and Jones (1992) supported the confrontation strategy. Jones (1995), attributing the implications of his instrumental theory, suggested that decreases of CSP are connected to a managerial entrenchment strategy. In a similar vein, Hill and Jones (1992) predicted that managers will undertake strategic actions to reduce stakeholder power - strategies that negatively affect corporate efficiency.

Our claim, as in Cespa and Cestone (2007), is the opposite: we hypothesize that stakeholders and incumbent managers will be natural allies, particularly when there are efficient internal corporate governance mechanisms capable of preventing managerial entrenchment impulses. In that case, collaboration with stakeholders cannot easily be blocked by shareholders, if based only on a 'suspicious' entrenchment strategy. This stimulates managers' incentives to improve CSP with entrenchment intentions. Hellwig (2000) pointed out that managers set on entrenchment will find allies in stakeholder sectors such as the political system, labor, the media, the judiciary, and universities.

In addition, the implementation of expensive policies aimed at improving a firm's CSP reduces its attractiveness to a raider. Generous long-term contracts with workers and suppliers, as well as long-term commitments to support environmental or philanthropic organizations are too heavy a burden to be borne by a raider (Pagano and Volpin, 2005). These concessions, however, are not fully internalized in share prices, for two reasons. First, as stakeholder theory researchers have already demonstrated (e.g., Berman et al., 1999), maintaining good relationships with key stakeholders creates an organizational resource that leads to more effective use of a firm's resources; this has a positive impact on financial performance. Therefore, in a context of information asymmetries, capital markets will be unable to determine if social concessions are a means of improving financial performance by generating a valuable organizational resource or if they are part of an entrenchment strategy (market inefficiency). And second, as mentioned earlier, social concessions related to the implementation of an entrenchment strategy are triggered mainly in the presence of strong internal corporate governance mechanisms. The existence of such mechanisms, together with the market inefficiency assumption, hinders any steep reductions in share prices.

Therefore, anticipating the impact of generous CSP initiatives in terms of reductions in stakeholder activism as well as reductions in the pressure from existing shareholders and potential raiders, we state the following hypothesis:

$\mathrm{H}_{1}$ : Managerial entrenchment practices have a positive impact on a firm's social performance. This effect is more pronounced in firms with efficient internal corporate governance mechanisms.

It is important to state that internal corporate governance mechanisms, while playing a positive moderating role by controlling the connection between entrenchment and CSP, also constrain managerial discretion. This would hinder the implementation of expensive socially responsible activities. That is, we also expect a negative direct effect of the internal governance mechanisms on a firm's CSP.

Finally, as mentioned before, agency theory shows that there is another conflict of interest within the firm that affects large and small shareholders, which may result in a minority expropriation by large shareholders. Some authors like Barnea and Rubin (2006) have argued that certain CSP activities may be connected to expropriation. Thus, managers may collude with large shareholders in order to expropriate minority 
shareholders by promoting intensive CSP policies. This collusion can be used as an entrenchment mechanism as it reinforces the managerial position with respect to the largest shareholders. Hence, in order to avoid this spurious connection between entrenchment and CSP, we have to control for variables that capture minority expropriation risks, such as ownership concentration.

\section{(i) Types of Stakeholders: Employees}

Within the managerial entrenchment strategy, workers constitute one of the stakeholder groups that receive preferential attention from the manager because they have the capacity to influence a firm's behavior and, at the same time, share common interests with incumbent managers. As a consequence, it is likely that entrenched managers, particularly those that face pressure from efficient internal corporate governance mechanisms, will commit themselves to giving employees more concessions (e.g., generous salaries).

The capacity of employees to influence decision-making, organizational arrangements and performance outcomes is well documented in previous literature (see for example, Schneper and Guillén, 2004). This power is derived from political action or legal mechanisms that are at their disposal. By political action we mean that workers may lobby against/in favor of an incumbent CEO by demonstrating, mobilizing politicians, appealing to the media, and constituting organized pressure groups like trade unions (Pagano and Volpin, 2005). In addition, the employees' power to promote or penalize top executives is amplified when they have institutionalized legal mechanisms at their disposal. One such mechanism is the presence of stakeholder directors on corporate boards, or board subcommittees such as the audit, compensation, executive, and nominating committees (Luoma and Goodstein, 1999). Furthermore, workers can directly affect the likelihood of CEO replacement through individual share ownership.

Importantly, employees are not only a powerful stakeholder group, but are natural allies of managers set on entrenchment. There is a vast literature that demonstrates that hostile takeovers have negative consequences for workers (Aguilera and Jackson, 2003) and that consequently they these tend to be opposed (Schneper and Guillén, 2004). In countries with low employment protection, a hostile takeover may result in job cuts and cause deterioration in working conditions. Successful raiders renegotiate the labor contracts that already exist, cutting wages to a minimum and stepping up monitoring to maintain workers' effort (Conyon et al., 2001).

In addition to the previous arguments, managers may be interested in colluding with employees, not only to gain their support, but also to reduce a firm's attractiveness to any potential raiders interested in companies with efficient internal corporate governance mechanisms. In such cases, employment policy is likely to be used to deter hostile takeovers (Pagano and Volpin, 2005), particularly in a context of inefficient financial markets that are more likely to be found in non-Anglo-Saxon countries. In these countries, social concessions to workers are more commonplace and difficult to reverse. Such arguments suggest the following hypothesis:

$\mathrm{H}_{2}$ : Managerial entrenchment practices have a positive impact on employee satisfaction. This effect is more pronounced in those firms with efficient internal corporate governance mechanisms. 


\section{(ii) Performance Analysis}

The instrumental approach is an important perspective of stakeholder theory (Donaldson and Preston, 1995). It advocates the formulation and implementation of activities that satisfy stakeholders because they control key resources and suggests that stakeholder satisfaction, in turn, will ensure the long-term survival and success of the firm (Freeman, 1984; and Hillman and Keim, 2001). Accordingly, stakeholders that own resources relevant to the firm's success will be more willing to offer their resources in the expectation of fulfillment of their different claims and needs (Strong et al., 2001). Therefore, under this approach we expect that stakeholder satisfaction will lead to higher commitment, greater effort, and, ultimately, to superior performance (Hosmer, 1994; and Stevens et al., 2005). Thus, stakeholder management has strategic value from a 'means to an end' perspective (Berman et al., 1999), which is opposed to the intrinsic value of the normative approach.

However, consistent with our previous propositions, we argue that when managers implement entrenchment practices, the negative effect of such practices on shareholders' value (Walsh and Seward, 1990; and Sundaramurthy, 2000) is reinforced with improvements in CSP.

Importantly, Sundaramurthy et al. (1997) and Sundaramurthy (2000) suggest that the strength or weakness of internal monitoring mechanisms, such as the board structure and the ownership concentration, moderate the relationship between certain entrenchment practices like anti-takeover provisions and shareholders' wealth. Remarkably, we have suggested in previous hypotheses, that a manager trying to insulate himself from internal monitoring mechanisms may also follow a generous policy of social concessions. Therefore, these managerial concessions to stakeholders, especially in the context of existing internal governance mechanisms that are efficient, should play a moderating role in the connection between the implementation of entrenchment practices and financial performance. McWilliams and Siegel (2001) termed these types of concessions as discretionary CSP and pointed out that it is negatively related to shareholders' wealth. Therefore, we expect this moderating role to be negative. Stated formally:

$\mathrm{H}_{3}$ : Managerial entrenchment practices when combined with social concessions have a negative impact on financial performance. This is particularly evident when social concessions are triggered in a context in which there are efficient internal governance mechanisms.

Finally, we expect that this result also holds good when we focus on the specific dimension of social performance: workers' satisfaction. This is because social concessions to workers are particularly costly and, at the same time, they strongly reinforce the entrenchment position of the manager with regard to shareholders, given the saliency of these stakeholders to achieve the firm's success. This stakeholder characteristic is particularly attractive in a context where efficient governance mechanisms aimed at preventing entrenchment are present. In such situations, social concessions, mainly to salient stakeholders like workers, will be needed in order to reinforce any entrenchment strategy. Hence, the negative impact of entrenchment on performance will be more evident when combined with workers' satisfaction:

$\mathrm{H}_{4}$ : Managerial entrenchment practices, when combined with social concessions to workers, have a negative impact on financial performance, especially in a context in which there are efficient internal governance mechanisms. 


\section{METHODS}

\section{(i) Sample and Variables}

We derive our sample by accessing different databases. The SiRi PRO ${ }^{\mathrm{TM}}$ database, compiled by the Sustainable Investment Research International Company ( $\mathrm{SiRi}$ ) - is the world's largest company specializing in socially responsible investment analysis. SiRi performs this analysis based on: reporting procedures, policies and guidelines, management systems, and key data. The necessary information is extracted from financial accounts, company documentation, international databases, media reports, interviews with key stakeholders, and ongoing contact with management. ${ }^{2}$ The information extracted from each firm is condensed into 199 information items that cover major stakeholder issues such as community involvement, environmental impact, customer policies, employment relations, human rights issues, activities in controversial areas (e.g., alcohol), supplier relations, and corporate governance. We complement these data on corporate responsibility with financial data from 2000-2005, extracted from OSIRIS, a database compiled by Bureau van Dijk (BvD) that provides information on financial, ownership and earnings for 38,000 companies, including listed, unlisted and de-listed companies from over 130 countries. Finally, we obtain data from Bloomberg on the MSCI world index in order to compute one of the variables of performance (the abnormal returns). The result of merging these databases is a sample composed of 358 industrial firms ${ }^{3}$ from 22 different countries, all included at least once in the $2002-2005$ period. ${ }^{4}$

\section{(ii) Measures}

Corporate social performance (CSP). This variable is approached through the SiRi PRO ${ }^{\mathrm{TM}}$ ratings. Five research fields are devoted to measuring the level of a firm's responsibilities to its stakeholders: community, customers, employees, environment, and vendors and contractors. Another section provides an overview of firms' corporate governance practices. However, we have excluded this part from our measure of CSP, because in our study we focus on the degree of satisfaction of the non-shareholders' stakeholders. For each stakeholder, the database addresses a firm's attributes in four areas: levels of transparency and disclosure; the existence of corporate policies and principles related to the stakeholder; the importance of management procedures; and the level of controversies with respect to this stakeholder. In each of these areas, there are information items that result in a Likert-type scale score ranging from 0 (worst) to 100

2 SiRi does not ask companies if they wish to be included in the survey. SiRi provides detailed profiles on the largest global companies in collaboration with SiRi's national partners. Each national partner, using harmonized methodology, scrutinizes social dimensions of the main corporations in its respective home market. Beginning with the largest companies, year-to-year, national partners expand the sample of companies analyzed, with the final objective of covering the whole home capital market (visit www.siricompany.com for more details).

3 Although our initial sample had 777 firms, we concentrate on the 358 firms that correspond to 448 observations from which we obtain information on all the variables needed to estimate our specifiations. This does not generate a bias because the mean values for the main variables in our sample are not significantly different from those of the original sample composed of 777 firms.

4 The distribution of observations among the most significant countries is: US (35\%), UK (12.1\%), Switzerland $(11.2 \%)$, France $(9.6 \%)$, Denmark $(7.1 \%)$, Spain $(4.9 \%)$, Italy $(3.6 \%)$ and Japan $(3 \%)$. 
(best). Importantly, each information item is weighted according to a methodology developed by SiRi. These weights are sector-specific and change annually. The corporate social performance indicator used in this study is the corresponding SiRi measure defined as the weighted sum of non-shareholders' stakeholder scores (the scores of community, customers, employees, environment, and vendors and contractors), using SiRi's weights but excluding the items that give information on transparency and disclosure for each stakeholder. This reduces any endogeneity problems because the level of disclosure of certain costly practices aimed at satisfying stakeholders' interests may have a clear impact on investment and disinvestment decisions by outside investors and may well trigger managerial entrenchment practices.

Workers' satisfaction (Workers). We approach this issue using the score for the level of a firm's responsibilities to its employees. This score is an aggregation of 37 indicators that cover different aspects of the firm's involvement in workers' issues. Also, in order to avoid endogeneity problems, we exclude the items related to transparency and disclosure from the definition of worker satisfaction.

Performance. We measure performance using three different proxies in order to provide more robust results. First, the return on assets (ROA), measured as the ratio of earnings before interest and tax to total value of assets. Second, Tobin's q; which is defined on a $\log$ scale as the ratio of the sum of market equity value, plus a firm's liabilities, to the total assets. Last, we use abnormal returns (Abn_Returns) computed using the MSCI world index as a factor. More specifically, these abnormal returns are computed as the difference of the expected monthly returns derived from a CAPM model using a window of five years from the firm's equity return in the corresponding year.

Managerial entrenchment. We use the measures for entrenchment provided by the SiRi $\mathrm{PRO}^{\mathrm{TM}}$ database that approximates the existence of anti-takeover devices, limitation of shareholders' voting rights, existence of multiple classes of stock with different voting rights, managers' stake and tenure. ${ }^{5}$ More specifically, Anti-takeover is a dummy that is equal to 1 if the firm has implemented any of the following anti-takeover measures: voting caps, increased voting rights over time, restrictions on board appointment rights, and poison pills. Shareholders_Rights is measured by a 3-point Likert scale: the highest value of this item corresponds to the situation in which major controversies have impact on the rights and treatment of shareholders, for example, governance arrangements that detrimentally affect the interests of shareholders, insider trading scandals involving company directors, or major conflicts of interest among board members. The intermediate value indicates the existence of controversies, both major and minor, but where the company has taken credible steps to resolve the problem. Finally, the other cases receive the lowest value. The variable OneShare_OneVote is a dummy that is equal to 1 if the company has multiple classes of stock with different voting rights, and is otherwise equal to 0. Gompers et al. (2006) demonstrate the perverse effect of having dual-class shares on firm value, caused by the distinction between cash-flow rights and voting rights. Concerning managerial ownership, the literature shows that this variable can also be used as an entrenchment device. To do so, we estimate Tobin's $q$ in terms of managerial ownership, its quadratic term, and cubic terms (Morck et al., 1988; and de Miguel et al., 2004). In the definition of

5 In the robustness section, we introduce another measure: the income smoothing. 
managerial ownership, we include the holdings of pension funds, bearing in mind that managers can exercise some influence in the composition of such a stake (Farinha, 2003). With regard to controls, we also incorporate size, leverage and investment, as defined below. The results show that the relationship between Tobin's $q$ and managerial ownership is decreasing in the range between $17 \%$ and $69.8 \% .{ }^{6}$ Hence, we characterize this entrenchment region with a dummy (Managown_Entrench) that is equal to 1 when managerial stake is in this region; and 0 otherwise. ${ }^{7}$ Finally, we have used a more direct measure of entrenchment that is also positively related to managers' holding; this is the manager's tenure. More specifically, Manager_Tenure is defined as a dummy that takes the value of 1 if the directors' term in office (including managers) is more than three years, and 0 otherwise. We choose this threshold because Fredrickson et al. (1988) show that a disproportionately large number of CEOs have tenure that lasts three years or less. In that case, a CEO with tenure larger than three years is a potential candidate to become a manager that follows entrenchment practices.

In addition to providing results using each indicator separately, we also aggregate the scores for these five indicators. The resulting score is labeled as Entrenchment. ${ }^{8}$ Also, in the specifications explaining market measures of performance, we do not include the variable Managown_Entrench (defined in terms of Tobin's q) in the definition of Entrenchment, in order to avoid endogeneity problems. Finally, we characterize large values of entrenchment through a variable DEntrenchment which is equal to Entrenchment when the value is larger than the mean of the sector for the corresponding year; and 0 otherwise.

Internal corporate governance mechanism. According to our framework, we apply controls to test the strength of internal corporate governance, using different variables to approach this issue. Audit_Committee, Nomination_Committee, and Remuneration_Committee are three dummy variables obtained from $\mathrm{SiRi}$; each one receiving the value 1 if such a committee exists with independent members. Due to the high correlation among these variables, we define Control_Committee as a 4-point Likert scale in which 0 represents the absence of any one of these committees and 3, the joint presence of independent audit, nomination, and remuneration committees. Non-dual_CEO is a dummy variable that is equal to 1 when the chairman is not the CEO, and 0 otherwise. Board_Independence is SiRi's Likert-type variable that takes three different values contingent on the percentage of independent directors with respect to the mean value of the sector. ${ }^{9}$ The highest value corresponds to the situation in which a majority of non-executive directors are considered independent; the intermediate value indicates that $50 \%$ or less of

6 In de Miguel et al. (2004), the range found using Spanish data is between $30 \%$ and $70 \%$.

7 The existence of an entrenchment region with intermediate values of managerial stake may explain that increases in managerial ownership may not prevent managers of behaving opportunistically and commiting fraud, even under the close scrutiny of financial markets (Sen, 2007).

8 For the sake of robustness, this variable has also been computed using the principal components of the aforementioned indicators and the results found remain the same, qualitatively.

9 According to the SiRi questionnaire, a director is not considered independent when assessing business may result in a conflict of interest. This precludes, among other things, a director that has held an executive position within the company group; and/or is on the board of a significant customer or supplier to the company; and/or has had an association with the company of more than nine years; and/or is related through blood, marriage or equivalent to other directors or advisers to the company. 
non-executive directors are independent; and zero in other cases. ${ }^{10}$ Performance_Evaluation is another SiRi Likert-type scale variable that can take three different values; it takes the value of 2 when two conditions are met: there is a board performance evaluation system, and there are no controversies on executive payments like payment unrelated to performance, the existence of golden parachutes, the repricing of options, or excessive pension benefits. This variable has a value of 1 when only one of the previous conditions is met and 0 in other cases.

Another mechanism for internal control is the role played by large shareholders. We studied this issue by employing measures of ownership concentration as well as the stakes in the hands of government. State_Ownership is the percentage of ownership in the hands of the state. Ownership_Concentration is the stake of the three largest blockholders, ${ }^{11}$ where we have excluded the manager's stake in order to avoid confounding effects with such a variable that is used as a proxy of entrenchment.

Finally, in order to study the existence of differential effects of entrenchment on CSP contingent on the aforementioned corporate governance mechanisms, we define the following variables that characterize situations with strong internal corporate governance mechanisms. DControl_Commitee is a dummy that is equal to 1 if the variable of Control_Committee is larger than the mean of the sector for the corresponding year; and 0 otherwise. Following the same logic we define DNondual, DBoard_Independence, DPerformance_Evaluation, DState_Ownership and DOwnership_ Concentration.

Control variables. We control for financial structure, dividends, size, firms' age, performance, investment, growth opportunities, industry, country, and year. To control for the financial structure, we use the variable Debt that measures the gearing of the company. This is defined as the ratio of non-current liabilities plus loans, to shareholders' funds. Dividend is the long-term dividend policy. This is characterized by the sector average pay-out ratio times the firm's after-tax profits. We have used this sectoral component in order to reduce potential endogeneity problems, given that stakeholder satisfaction has a clear impact on the proportion of funds transferred to shareholders (pay-out ratio). Size is the value of fixed assets; and Age is the number of years of the company's existence. We include the aforementioned return on assets (ROA) as a control for financial performance in the specifications of CSP as dependent variable. Investment is the ratio of fixed assets to total assets. Growth is equal to 1 when the rate of increase in sales is larger than the value for the corresponding sector and year, and 0 otherwise. Intangibles is the ratio of intangible assets to total fixed assets. In some specifications, we classify the countries according to the origin of their legal codes. We follow La Porta et al. (1998) in distinguishing four types of countries according to the origin of a country's legal code: (i) British common law, (ii) French civil law, (iii) German civil law, and (iv) Scandinavian civil law.

10 The effectivity of the board of directors as control mechanism will depend negatively on the power of the manager (Lasfer, 2006) but positively on external control mechanisms like the product market competition (Bozec, 2005).

11 Alternatively, we use the stake of the largest shareholder and that of the five largest, and the results remain qualitatively the same. 
We rely on two basic specifications to contrast our hypotheses, one explaining CSP in terms of entrenchment and corporate governance; the other to explain performance in terms of entrenchment and CSP.

We estimate our specifications using panel-data techniques; ${ }^{12}$ clustering the standard errors by firm (Petersen, 2006) in order to prevent firm effects given the persistence of the measures of social performance. ${ }^{13}$ In accordance with Petersen (2006), we do not cluster the standard errors by year because the variability of CSP in each year is already high enough (three times larger than the variability by firm).

In order to explain a firm's CSP together with worker satisfaction and test hypotheses 1 and 2, we consider the following basic specification: ${ }^{14}$

$$
\begin{aligned}
\text { CSP }_{i t+1}= & \alpha_{1}+\alpha_{2} \text { Entrenchment }_{i t}+\alpha_{3} \text { Control_Committee }_{i t}+\alpha_{4} \text { Non-dual_CEO }_{i t} \\
& +\alpha_{5} \text { Board_Independence }_{i t}+\alpha_{6} \text { Performance_Evaluation }_{i t} \\
& +\alpha_{7} \text { State_Ownership }_{i t}+\alpha_{8} \text { Ownership_Concentration }_{i t}+\alpha_{9} \text { Debt }_{i t} \\
& +\alpha_{10} \text { Dividend }_{i t}+\alpha_{11} \text { Siz }_{i t}+\alpha_{12} \text { Age }_{i t}+\alpha_{13} \text { ROA }_{i t}+\alpha_{14} \text { Investment }_{i t} \\
& +\alpha_{15} \text { Growt }_{i t}+\alpha_{16} \text { Intangibles }_{i t}+\varepsilon_{i t} .
\end{aligned}
$$

We conduct further estimations of specification (1) ${ }^{15}$ by breaking the variable Entrenchment into its basic components: Anti-takeover, Shareholders_Rights, OneShare_OneVote, Managown_Entrench, and Manager_Tenure. Also, to study the possible moderating effect of the variables of governance, we crossed the aforementioned variable DEntrenchment times the dummies, measuring the strength of internal governance mechanisms. The resulting multiplicative variables are the following: DControl_Committee $*$ DEntrenchment, DNon-dual $*$ DEntrenchment, DBoard_Independence* DEntrenchment, DPerformance_Evaluation $*$ DEntrenchment, $\quad$ DState_Ownership* DEntrenchment, and DOwnership_Concentration $*$ DEntrenchment. We focus on significant values of entrenchment because we expect them to appear as a reaction to the existence of strong internal control mechanisms. In such situations we have argued that CSP would be used as part of an entrenchment strategy (hypothesis 1).

It is important to stress that by using fixed-effect estimations, we eliminate the unobservable heterogeneity that may be potentially correlated with the independent

12 For robustness (available upon request from the authors), we have also used cross-section estimations, and the main results coincide with those found using panel-data techniques.

13 To test whether the effects are fixed or random, we used the Hausman test. When this test reveals that there is no correlation between the firm-specific error component and the explanatory variables, we use randomeffects estimations because it is the most efficient alternative (Arellano and Bond, 1991). The results show that a majority are fixed-effect estimations.

14 We rule out specifications that include the dependent variable lagged by one period because the persistence in CSP may generate endogeneity problems that can only be tackled through GMM estimations. Unfortunately, the limited number of years available does not permit us to use such a technique. Nevertheless, in an unreported estimation, available upon request from the authors, we introduce the dependent variable lagged by one period and estimate such a specification using clustered fixed effects. The results found are consistent with those reported in Table 3 and, remarkably, the coefficient of the CSP variable lagged by one period is not very significant. This may suggest that the question of persistence does not significantly bias the results.

15 For estimates using fixed effects, temporal, sectoral and country dummies are not needed. For randomeffects estimation, we correct by temporal, sector and country effects by detracting from the dependent variable its mean value for the corresponding year, sector and country. 
variables. For example, the intrinsic characteristics of the manager should condition a firm's CSP activities and, at the same time, may be connected to the definition of an entrenchment strategy as well as with the governance characteristics of the firm. Additionally, as we explain in the theoretical section, we expect that pressure from different stakeholders is connected to different internal corporate control mechanisms. This means that an endogeneity problem in specification (1), which is not directly connected to the unobservable heterogeneity, may exist perfectly. We tackle this problem by advancing the dependent variable by one period.

Concerning hypothesis 2 , we slightly modify the previous specification and substitute the dependent variable of CSP with that of Workers' satisfaction (Workers).

In order to test hypotheses 3 and 4 , we focus on a specification that defines corporate financial performance in terms of entrenchment and CSP. The basic specification is:

$$
\begin{aligned}
\text { Performance }_{i t+1}= & \beta_{1}+\beta_{2} \text { Entrenchment }_{i t}+\beta_{3} \mathrm{CSP}_{i t}+\beta_{4} \text { DEntrenchment_DCSP }_{i t} \\
& +\beta_{5} \text { Control_Committee }_{i t}+\beta_{6} \text { Non-dual_CEO }_{i t} \\
& +\beta_{7} \text { Board_Independence }_{i t}+\beta_{8} \text { Perform_Evaluation }_{i t} \\
& +\beta_{9} \text { State_Ownership }_{i t}+\beta_{10} \text { Ownership_Concent }_{i t}+\alpha_{11} \text { Debt }_{i t} \\
& +\alpha_{12} \text { Dividend }_{i t}+\alpha_{13} \text { Size }_{i t}+\alpha_{14} \text { Age }_{i t}+\alpha_{15} \text { Investment }_{i t} \\
& +\alpha_{16} \text { Growth }_{i t}+\alpha_{17} \text { Intangibles }_{i t}+\varepsilon_{i t .}
\end{aligned}
$$

From this specification, we test whether entrenchment when combined with a variation in CSP (hypothesis 3) or in workers' satisfaction (hypothesis 4) has further negative effects on financial performance. This test requires the inclusion of an interaction term between variations in CSP and entrenchment practices. Moreover, consistent with what we have mentioned in the theoretical section, we expect the complementarity between both variables (entrenchment and increases in CSP) to appear mainly in a context with efficient governance mechanisms, where managers who are set on entrenchment will reinforce their strategy with the implementation of socially responsible actions. In such situations, we expect intensive managerial entrenchment complemented with improvements in socially responsible actions. Thus, we focus on the interactive variable DEntrenchment_DCSP that crosses the aforementioned variable DEntrenchment, which is equal to Entrenchment when entrenchment is larger than the mean of the sector for the corresponding year, with variations in CSP (DCSP). Following the same logic, we define DEntrenchment_DWorkers. Then, the complementarity hypothesis is supported if the coefficient of such a variable is negative.

\section{RESULTS}

Table 1 shows information on the distribution of each variable of our study. The data show that CSP has a median value which is in the middle of its range of definition $(49.4)^{16}$ while for Workers it is slightly higher (53.7). For Entrenchment, the median value is 1 in a range between 0 and 4 and the ROA, as a variable of performance, has

16 Luxemburg, Finland, and Denmark are the countries with the largest values of CSP. Remarkably, Denmark is also among the countries with the largest values for the entrenchment variable, which is in line with our theoretical contention that relates both variables positively. 


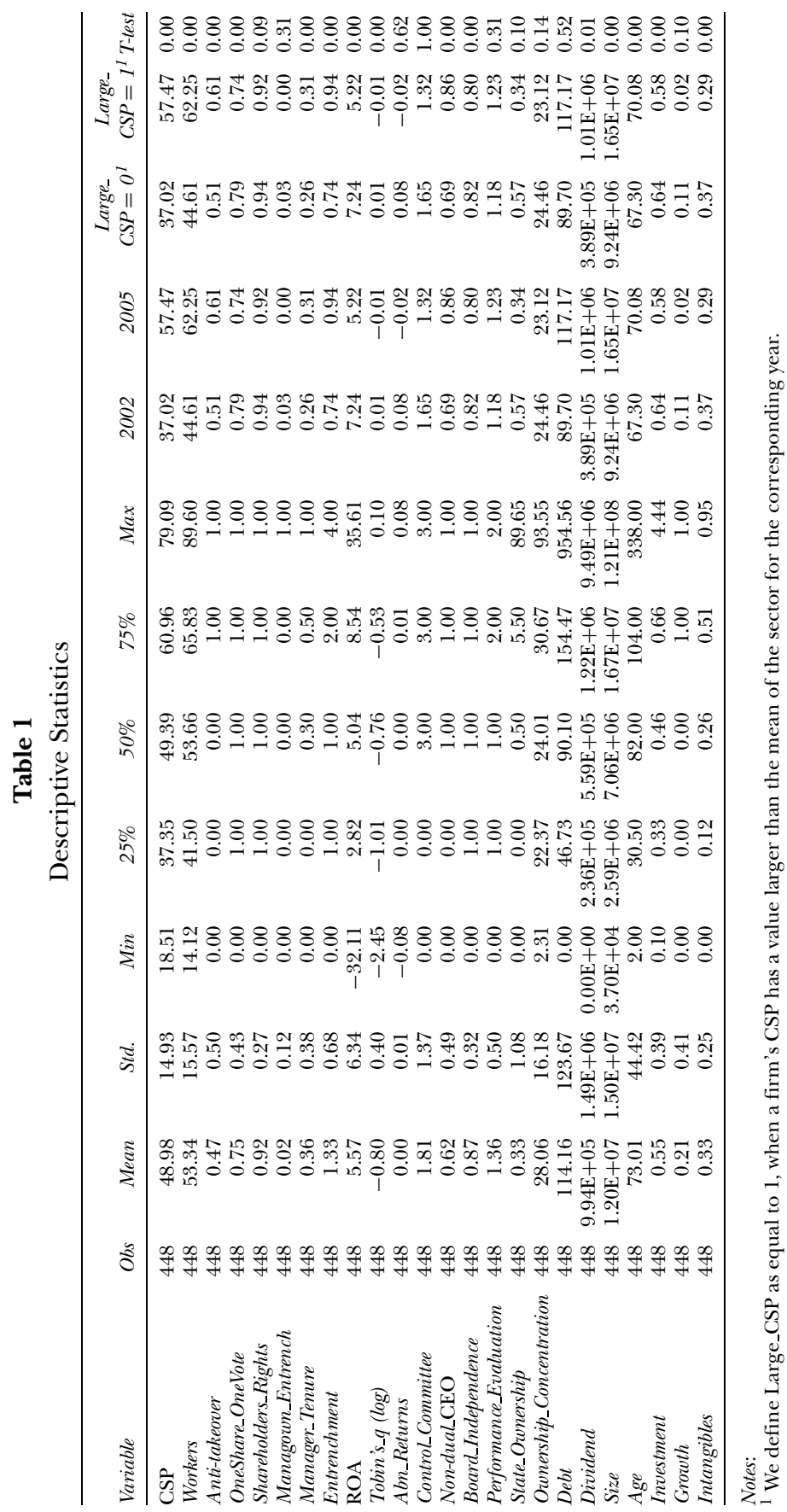


a median value of $5 \%$. Concerning the variables for internal control mechanism, their median values are 3, 1, 1 and 1 for Control_Committee; Non-dual_CEO; Board_Independence and Performance_Evaluation respectively, and for the remaining variables for internal control mechanisms, State_Ownership has a value of $0.5 \%$ and the sum of the stakes of the three largest shareholders (Ownership_Concentration) is $24 \%$. Finally, in terms of the control variables, the median size of a company in the sample is $€ 7,064$ million; the age is 82 years; firm Debt is $90 \%$, the Investment variable has a median value of $45.9 \%$ and the median proportion of Intangibles is $26.3 \%$.

Then, the inspection of this second quartile (median values), reveals that almost all variables have non-null values. ${ }^{17}$ This eliminates concerns about the existence of truncated distributions around the zero value. Table 1 also shows the evolution of the variables comparing the first year of the sample (2002) with the latest one (2005). It is remarkable that the variable for CSP increases steadily from a value of $37 \%$ in 2002 to a value of $57.5 \%$ in 2005 . This reflects the growing interest in socially responsible activities over time. ${ }^{18}$ Precisely this fact allows using such activities as a managerial entrenchment mechanism. Finally, in Table 1, we present a mean test analysis comparing firms with large values of CSP to their counterparts. We find that among the companies with large values of CSP, the Entrenchment variable has significantly larger values than its counterparts (0.9 versus 0.7$)$; while the variables for Performance show lower ones (5.2 versus 7.2 for ROA). This conforms to our theoretical contentions.

Table 2 displays the correlation matrix. On inspection of the correlation matrix, we find that the variable of entrenchment is positively correlated $(7 \%)$ with that of CSP. ${ }^{19}$ This is particularly evident for anti-takeover initiatives, the deterioration of voting rights (OneShare_OneVote) as well as managerial tenure. Additionally, CSP is also negatively correlated to different internal control mechanisms like the nonduality between the CEO and the chairman of the board (Non-dual_CEO), and the proportion of independent directors. We interpret these results as evidence that, when entrenchment is more difficult as a result of internal control pressures, CSP initiatives are also less likely. However, we show in the following analysis that, if firms are able to define a significant entrenchment strategy within a framework where internal governance mechanisms are well developed, this has a positive impact on a firm's CSP.

Table 3 summarizes the regression analysis of specification (1), whereby we test the effect of managerial entrenchment practices on CSP. Further, in Column 1 we break the variable Entrenchment into its five components: Anti-takeover Shareholders_Rights, OneShare_OneVote, Managown_Entrench and Manager_Tenure. We find that anti-takeover measures, as well as managerial tenure, have a positive impact on CSP. Also, when managers' stake moves into the 'entrenchment region' (between $17 \%$ and $69.8 \%$ ), it has a positive impact on CSP. A second result shows that when entrenchment is more

17 Among the exceptions there are two components of the entrenchment variable (Anti-takeover and Managown_Entrench), although the aggregate entrenchment variable has a non-null median value.

18 For example, in the report 'Green, Social, and Ethical Funds in Europe: 2005 Review' of Avanzi SRI Research and SiRi, we have observed a substantial increase in the number of SRI funds since 2003, and more importantly that the total amount of SRI assets grew by about $99 \%$ : from a value of $€ 12$ billion, in 2003 , to a value of $€ 24$ billion at the end of the second quarter of 2005 . This gives us an idea of the increasing importance of social performance, as these ethical funds invest only in firms with high ratings in CSP.

19 This result is more significant when we look at variations in CSP; they are positively correlated with those variations of entrenchment $(13.6 \%)$. The correlations in differences for other variables show qualitatively the same results and are available upon request from the authors. 


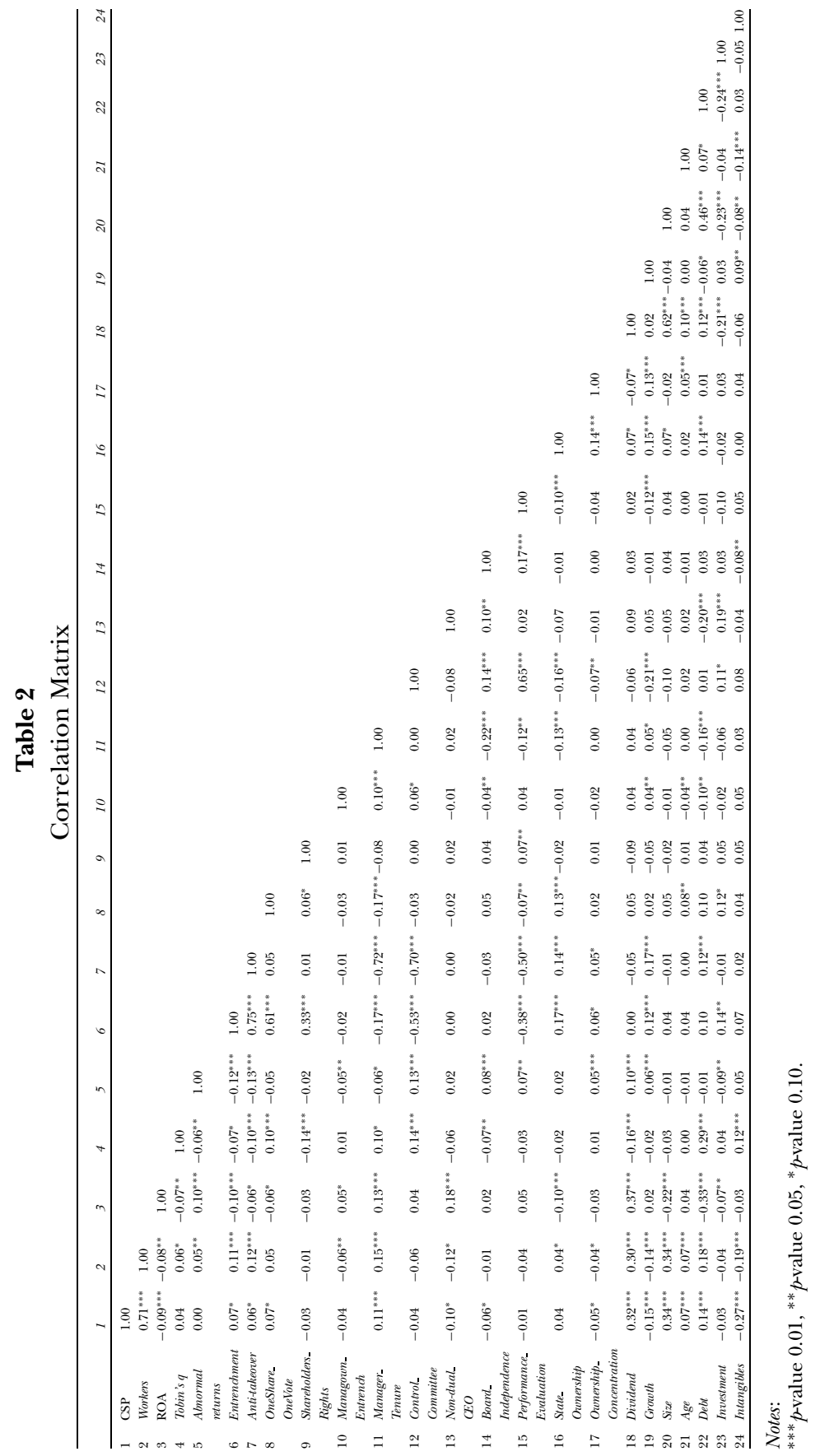




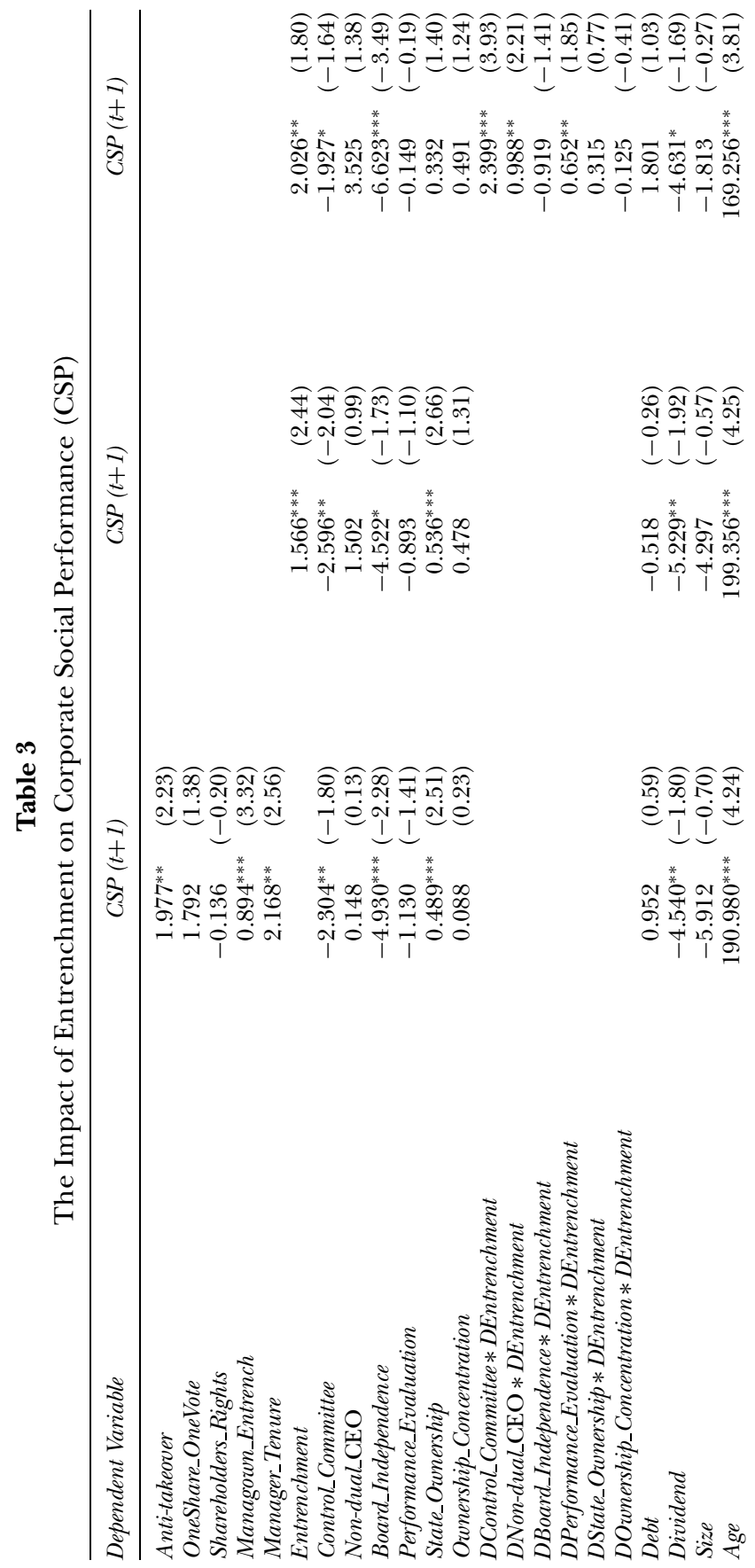




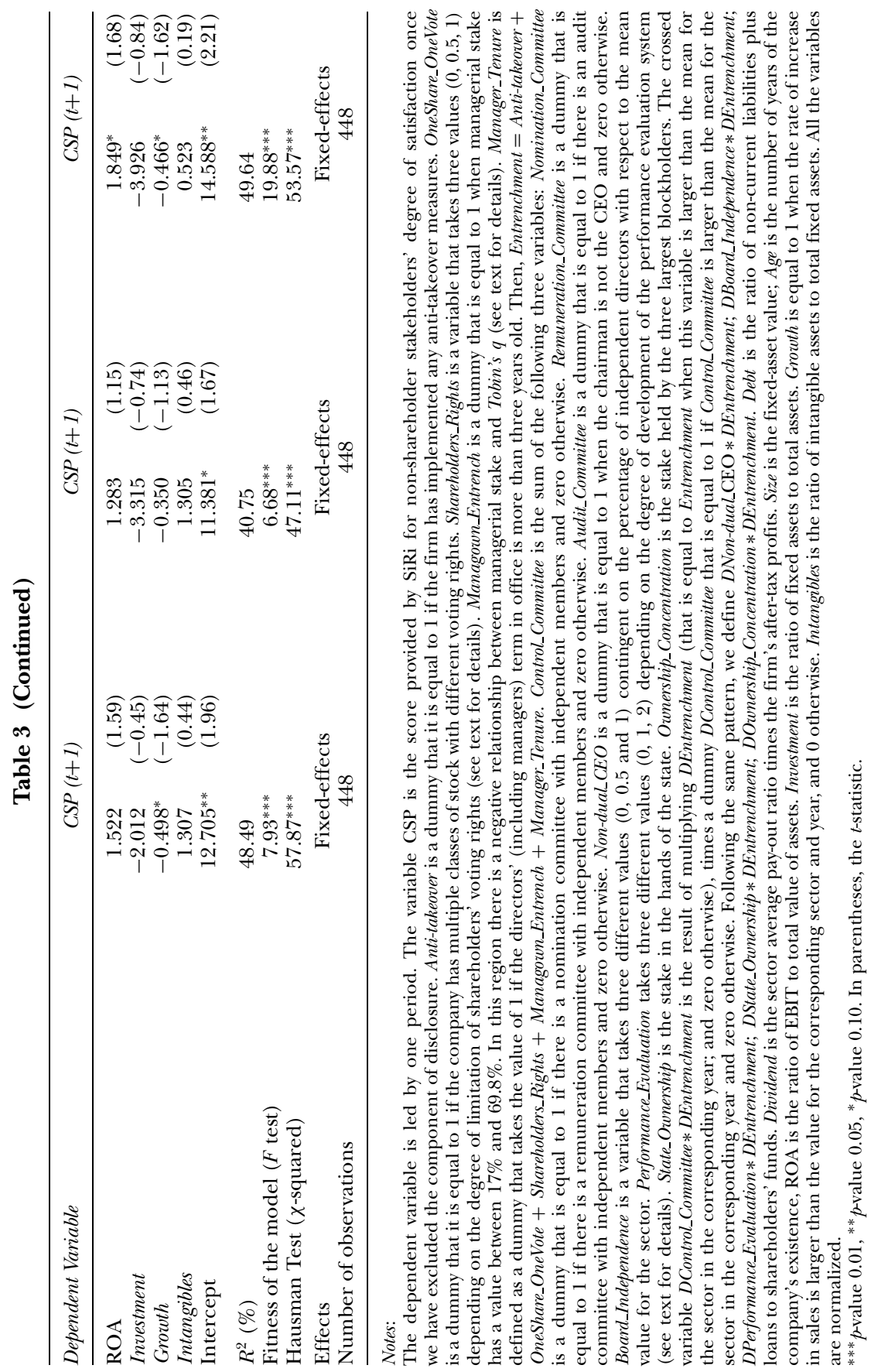


difficult, due to the presence of a significant proportion of independent members on the board, or the existence of independent control committees, there is a negative impact on CSP. This reflects the complementarity idea between entrenchment and CSP on which this paper relies. Moreover, the aggregate measure of entrenchment has a positive impact on CSP (Column 2). Once we look at the coefficient of the multiplicative variables (Column 3), we find that entrenchment has a particularly positive impact on CSP in those scenarios where entrenchment is more difficult ex-ante - mainly, that is, when the number of control committees with independent members is larger than the mean for the sector in the corresponding year; when there is a separation between the CEO and the chairman of the board, as well as when the performance evaluation systems are more developed than the average for the corresponding sector and year. In such cases, corporate governance is more developed and, if the manager is set on entrenchment, he complements this strategy with increases in CSP. This conforms to hypothesis 1 .

In addition, we find that a generous dividend policy hinders the implementation of policies aimed at satisfying non-shareholder stakeholders. This result is in accordance with the slack resources hypothesis of Waddock and Graves (1997), which suggests that better financial performance results in a surplus of resources that provides firms with the financial wherewithal to consider and do something about social issues. Finally, and consistent with the growing interest in CSP issues, older firms (with an accumulated reputation) show larger values in CSP.

Once we focus on workers' satisfaction (Table 4), the results are, in essence, the same as those for the overall score of CSP. This conforms to hypothesis 2. The significant coefficient of anti-takeover measures in explaining a firm's CSP is remarkable. This is in accordance with Pagano and Volpin (2005), where wage concessions - that improve workers' satisfaction - are described as anti-takeover initiatives. The positive sign for the State_Ownership variable can be explained in terms of the willingness of government-owned firm managers to satisfy workers as part of an entrenchment strategy, given that public authorities consider workers as potential constituencies. This will reinforce the position of managers in such firms. A similar argument can explain the positive moderating role of the State_Ownership variable in the connection between entrenchment and CSP. Finally, the non-negative sign of the dividend variable can be explained by the fact that workers may well have shares in the firm. In fact, the non-significant sign may be the result of compensating the positive effect, due to the dividends received, with the negative effect as dividends reduce the available resources for satisfying workers' interests.

In order to analyze the consequence of entrenchment combined with CSP, we show in Tables 5A, 5B and 5C the results of estimating specification (2) using different measures of performance. In Table 5A, we use ROA; in Table 5B, Tobin's q; and in Table 5C, abnormal returns derived from a single factor model. ${ }^{20}$

20 Given the endogeneity between market measures of performance and ownership structure (Demsetz and Villalonga, 2001), we have detracted from the variable of entrenchment the component on managerial ownership in those estimations that use market measures of performance (Tables $5 \mathrm{~B}$ and $5 \mathrm{C}$ ). Note that one of the components of entrenchment (Managown_Entrench) is defined in terms of a decreasing relationship between managerial ownership and Tobin's $q$. 


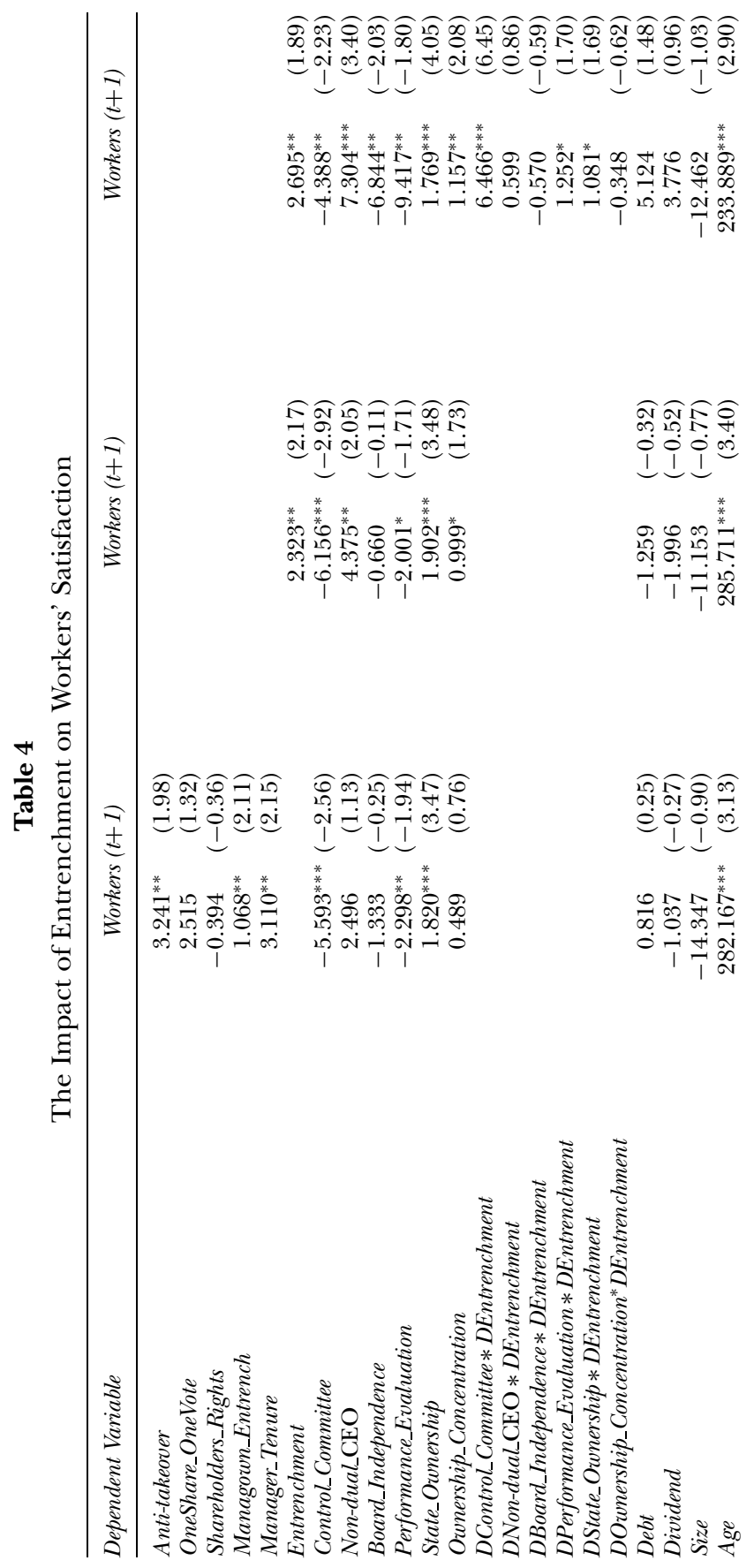




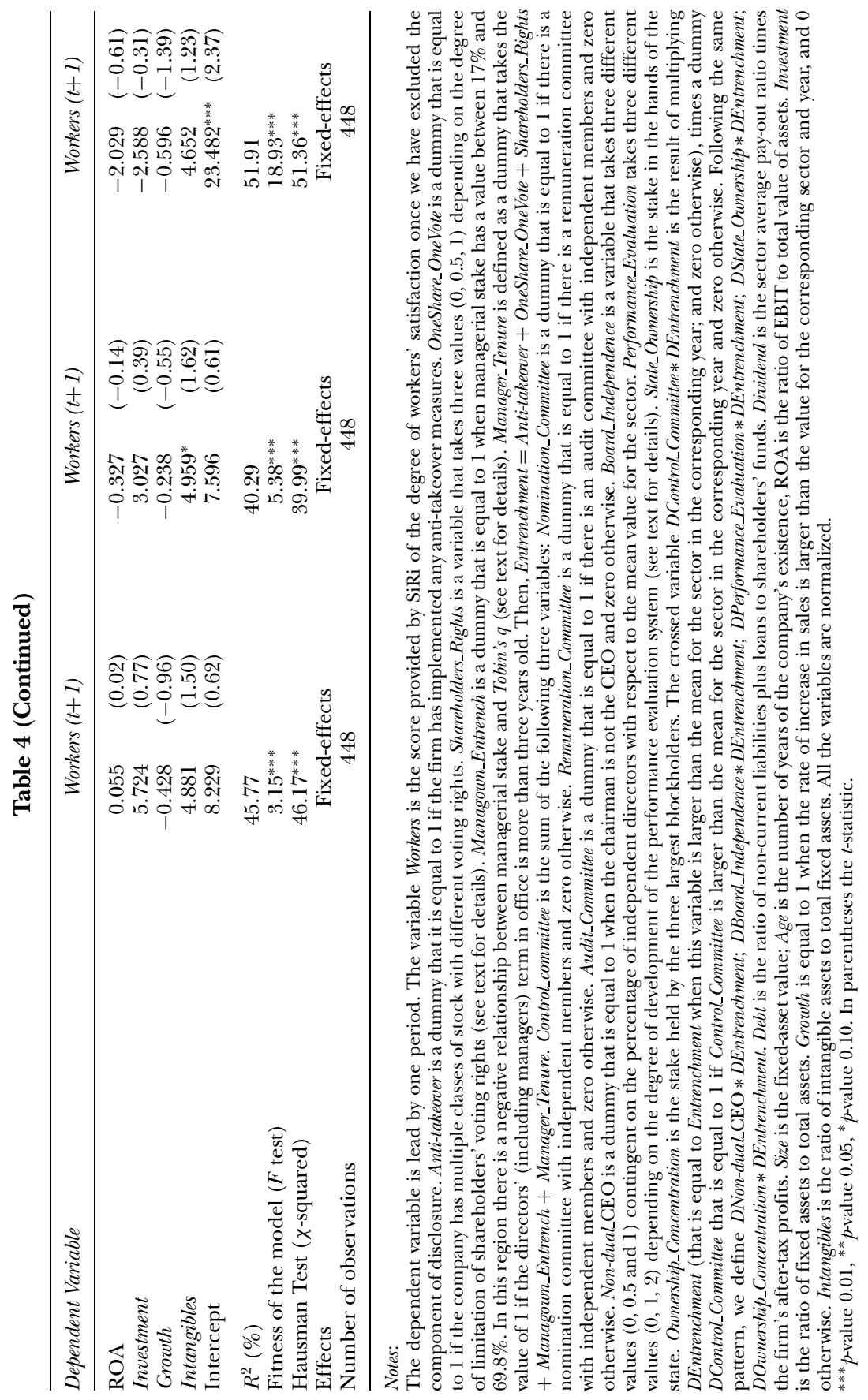




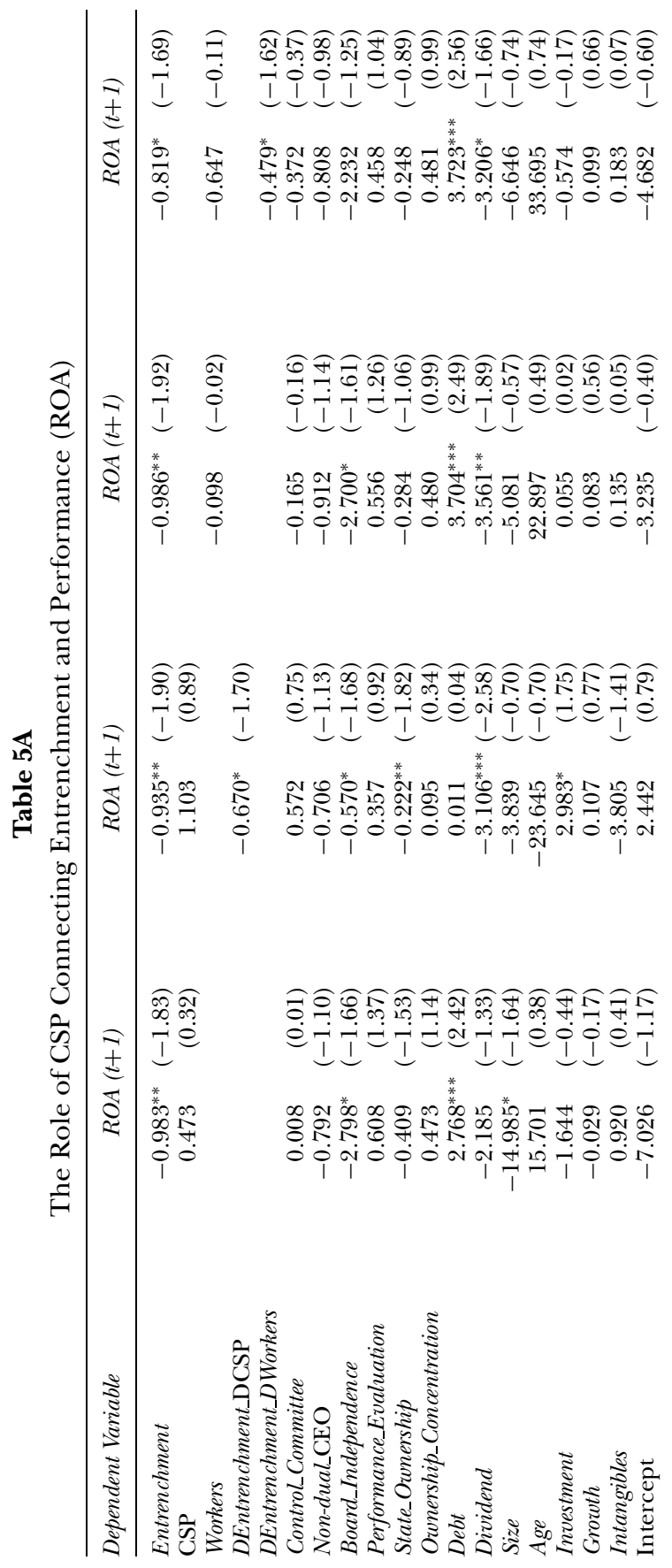




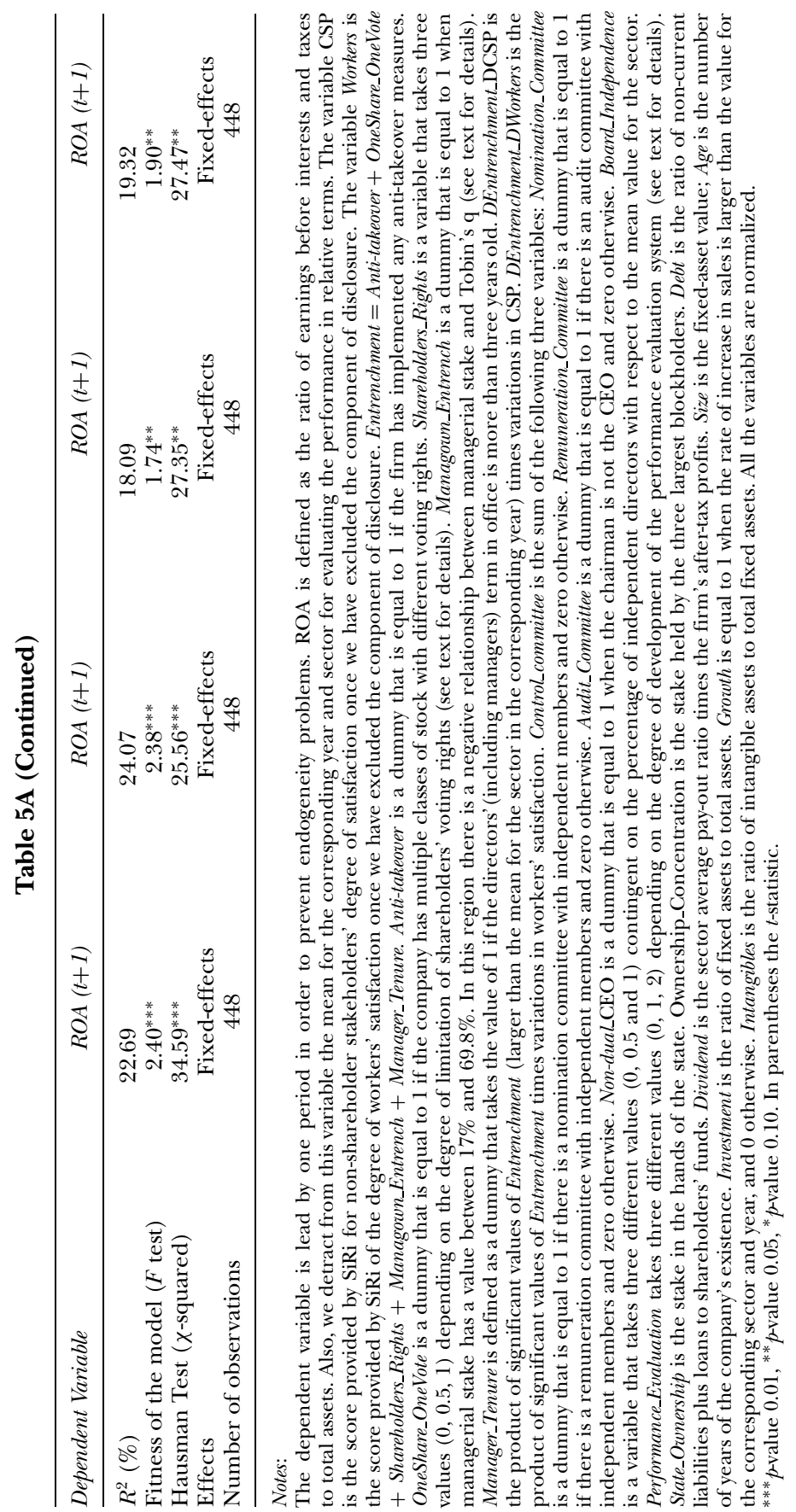




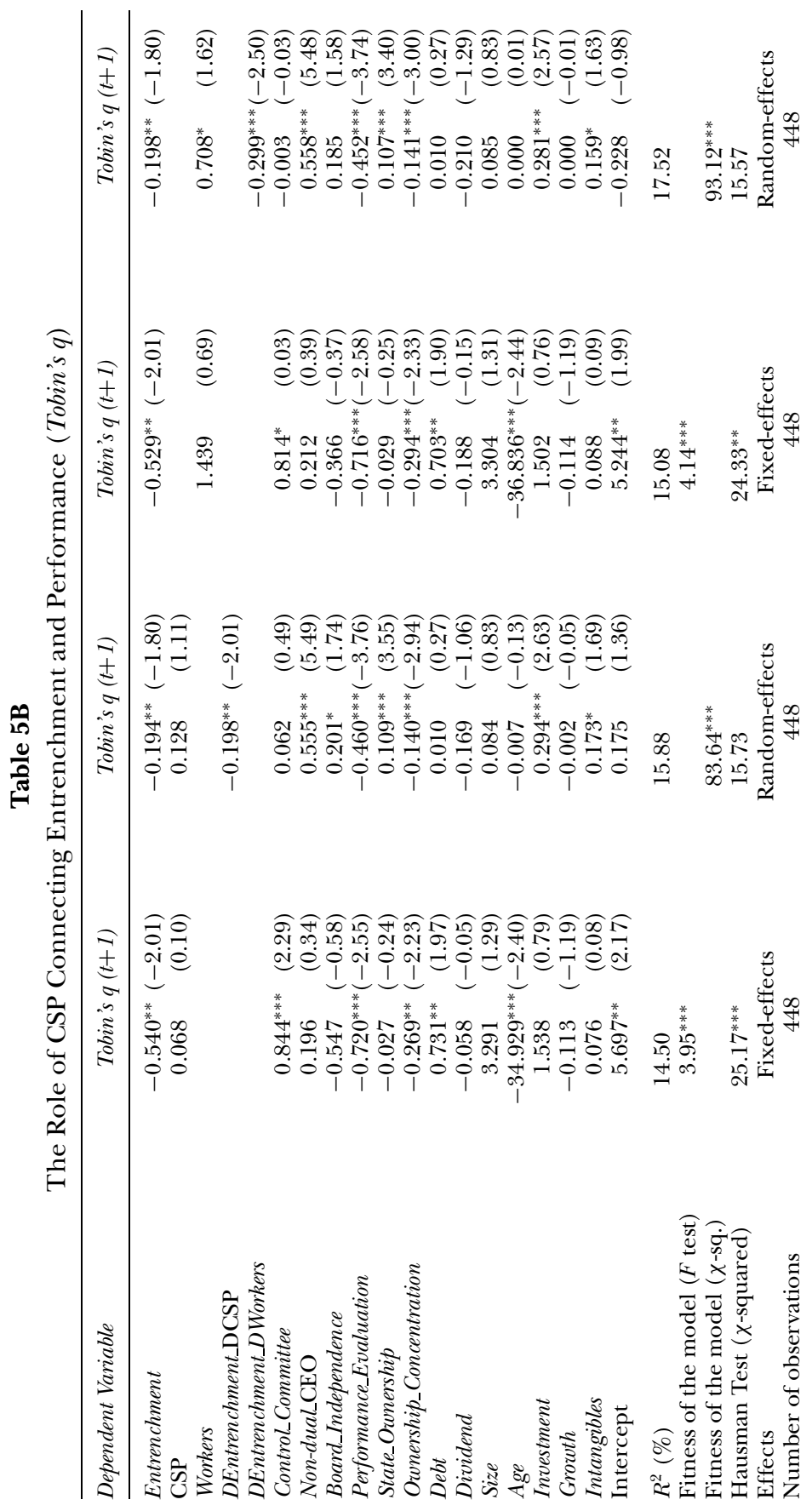




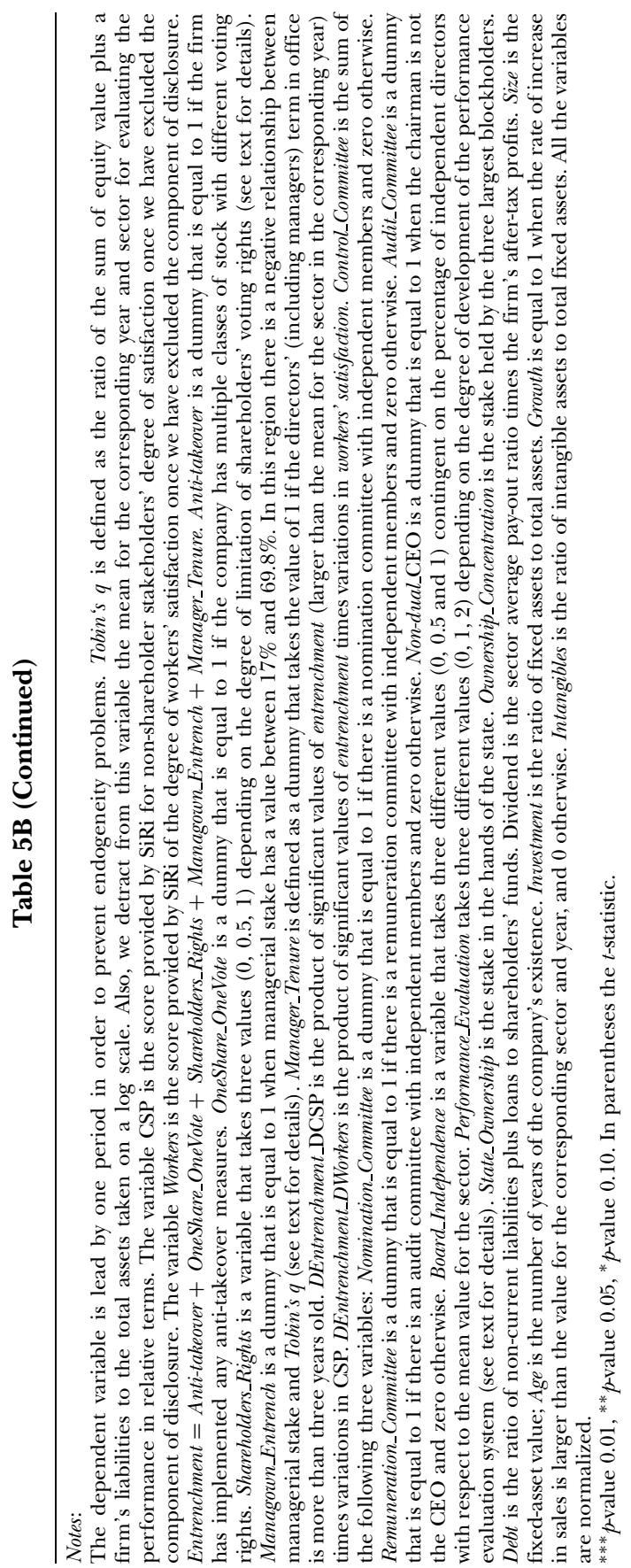




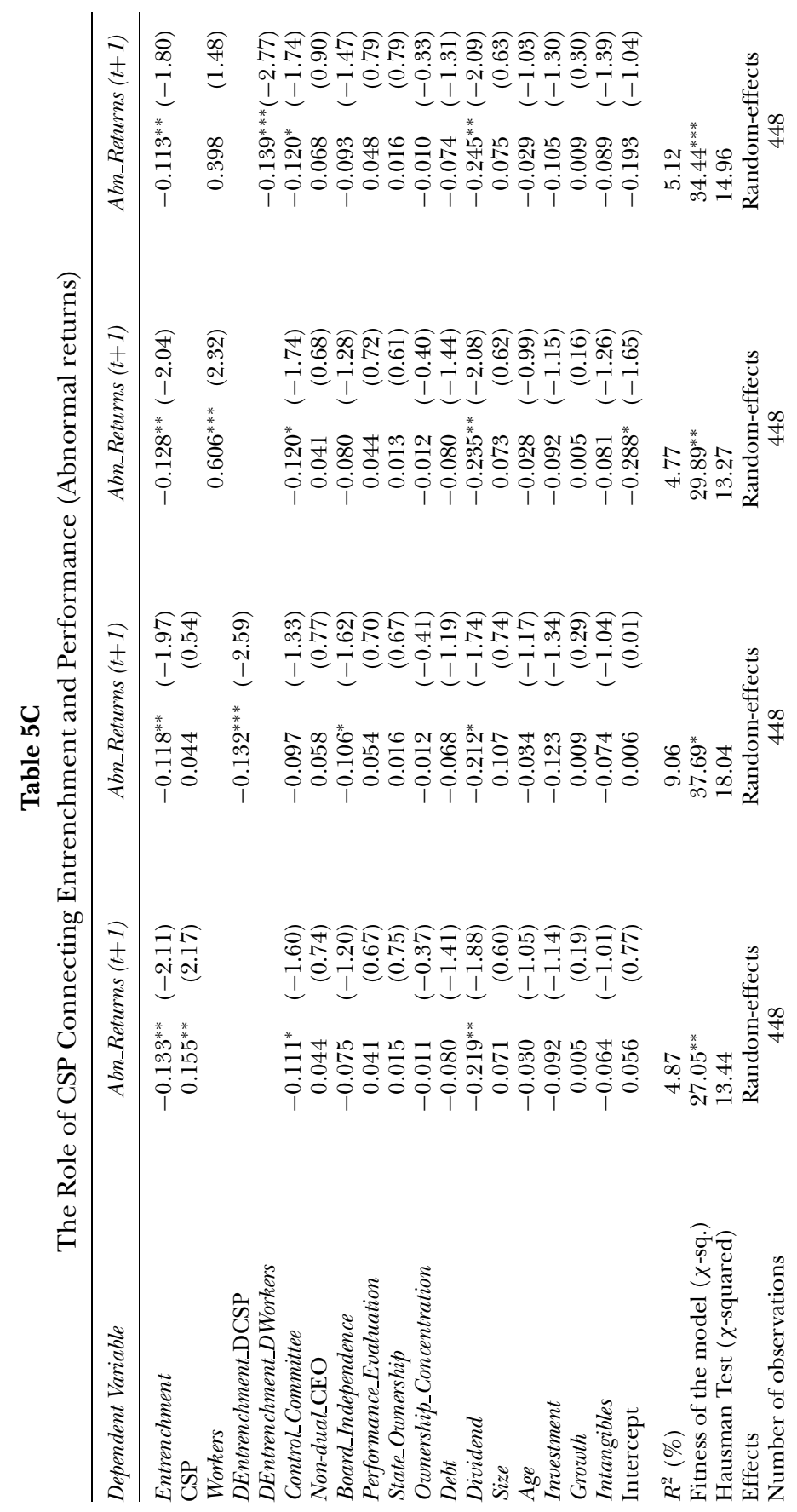




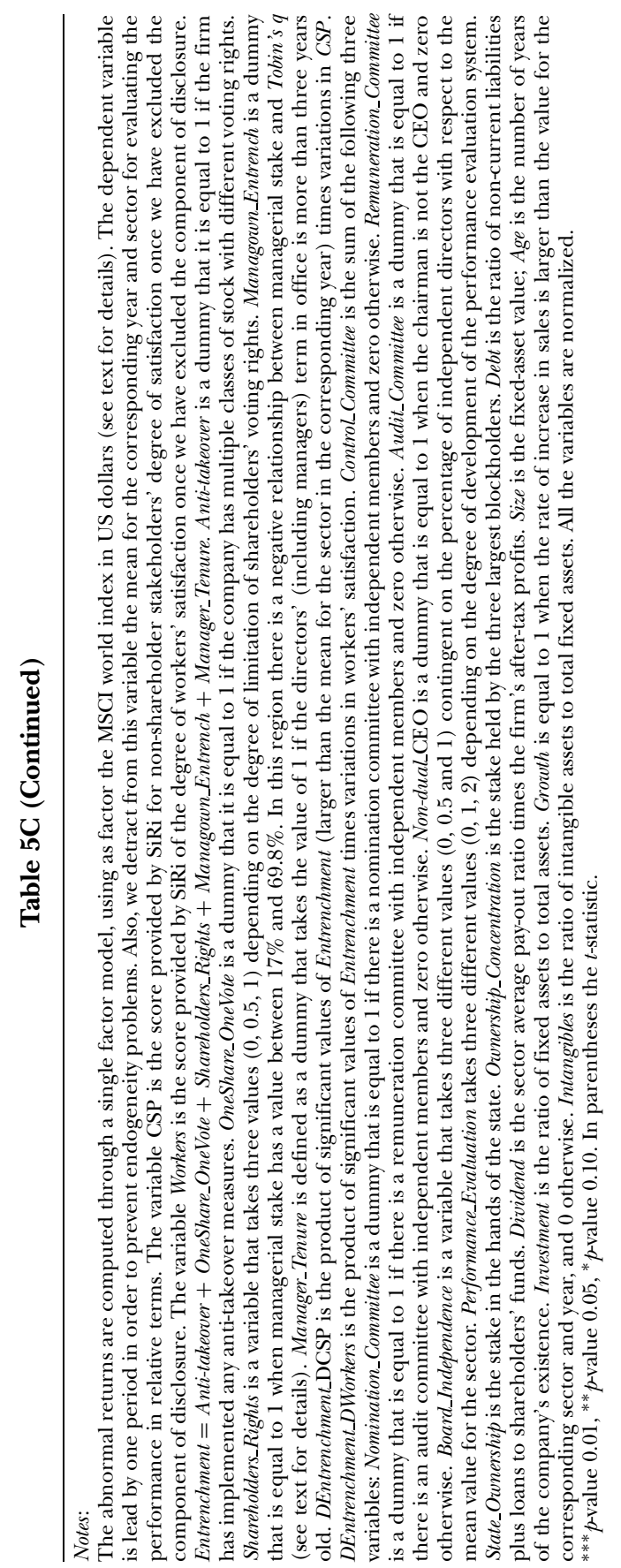


Once we focus on the estimations for $\mathrm{ROA},{ }^{21}$ we find that entrenchment has a negative impact on ROA, a result which is consistent with previous literature (e.g., Jensen and Ruback, 1983). Also, we find that this effect is more significant when entrenchment is large and is defined in combination with increases in CSP (Column 2) and in workers' satisfaction (Column 4). That is, there is a complementary relationship between both variables: when there is an increase in social performance and/or in workers' satisfaction, the marginal effect of entrenchment; when significant, the effect on the returns on assets is more negative. This conforms to hypotheses 3 and 4 .

It is important to highlight that the results hold good for significant values of entrenchment (larger than the mean for the sector and year). We have argued previously that this corresponds to situations of large internal control, where we expect that entrenchment, when it appears, triggers increases in socially responsible policies that reinforce the power of the manager. This generates a decrease in performance. Among the control variables, the positive effect of debt on performance is noteworthy. This effect may be explained by the fact that it reduces managerial discretion (Jensen, 1986) and/or improves efficiency (Margaritis and Psillaki, 2007).

The results on Tobin's $q$ and abnormal returns (Tables $5 \mathrm{~B}$ and $5 \mathrm{C}$ respectively) conform to those using ROA and are even clearer. Given the previous set of results, we provide support for the thesis regarding the existence of an entrenchment motive to justify certain increases in CSP, particularly when managerial control mechanisms are well developed. In this case, entrenchment is less likely. However, if it does occur, it is so intensive that it also triggers socially responsible actions. This is a reinforcing mechanism, given that managerial collusion with non-shareholder stakeholders allows them to channel stakeholders' power against shareholders. In this situation there is a clear negative impact on financial performance.

\section{ROBUSTNESS}

\section{(i) Income Smoothing}

In order to investigate the robustness of our results, we maintain that one form of earnings manipulation - income smoothing - is an additional entrenchment mechanism. Managers smooth earnings as a natural entrenchment strategy in order to ensure a stable stream of profits that will satisfy shareholders (Fudenberg and Tirole, 1995). However, although earnings manipulations improve financial performance in the short term, they damage the medium-term interests of shareholders. The manager anticipates this fact and has all the incentives to trigger entrenchment initiatives. Within this setting, we characterize a situation where we expect, according to our theory, to find an increase in CSP. This is a way to test the robustness of our results.

To test this contention, we use two alternative measures of income smoothing (Leuz et al., 2003). First, we approach this variable through the correlation between changes in accruals and changes in cash flow (Incsmooth1), where Accruals $=(\Delta \mathrm{CA}-\Delta$ Cash $)-$ $(\Delta \mathrm{CL}-\Delta \mathrm{STD})-\mathrm{DEP}$, when $\Delta \mathrm{CA}$ is the change in current assets; $\Delta$ Cash is the

21 All variables of performance are defined in relative terms by subtracting the mean of the sector and year from each firm's performance value. This definition gives information on the real performance of each firm when compared with the average for each sector in the year analyzed. Also, the demeaning of performance allows us to eliminate sectoral, temporal and country effects. 


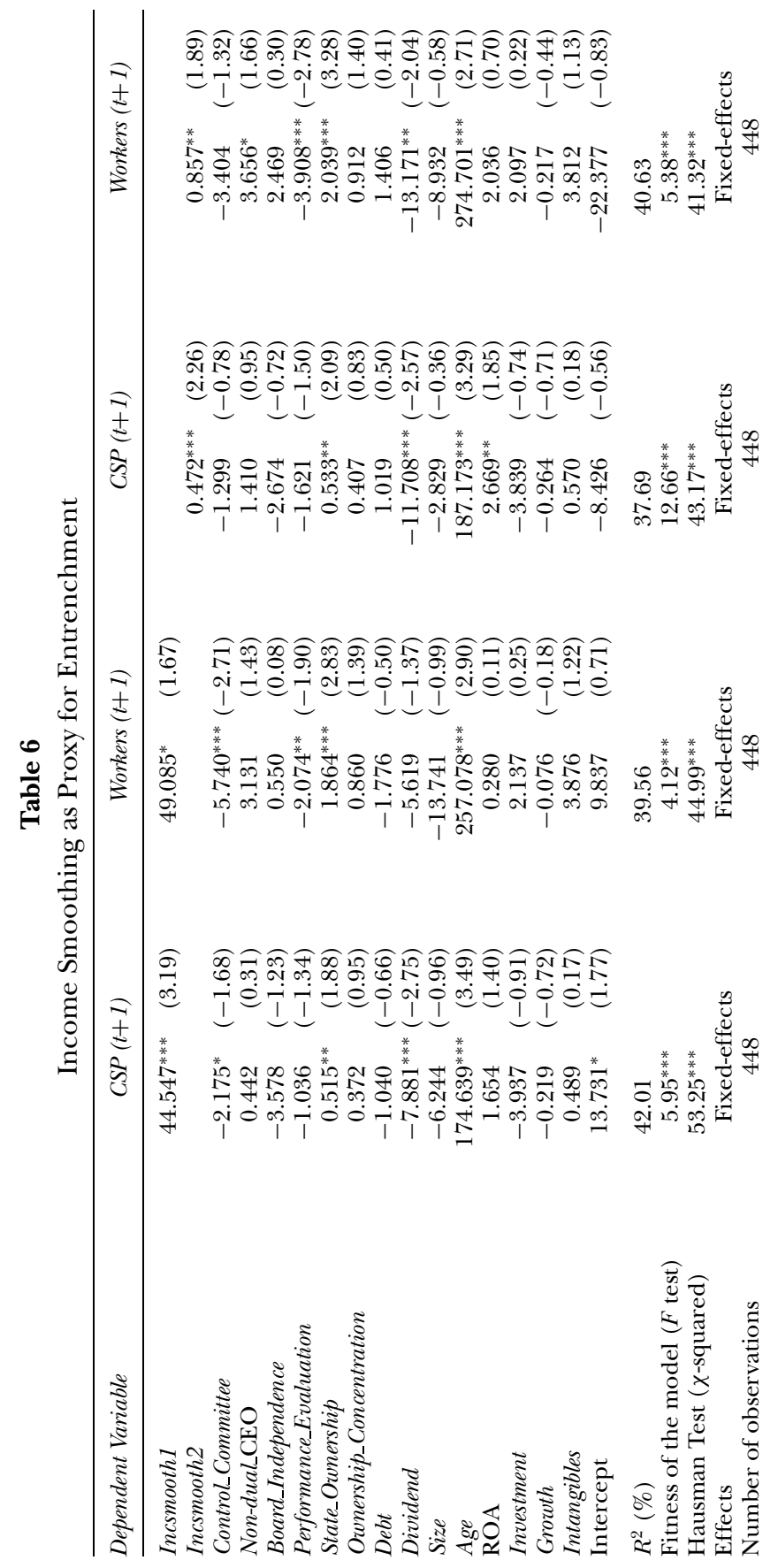




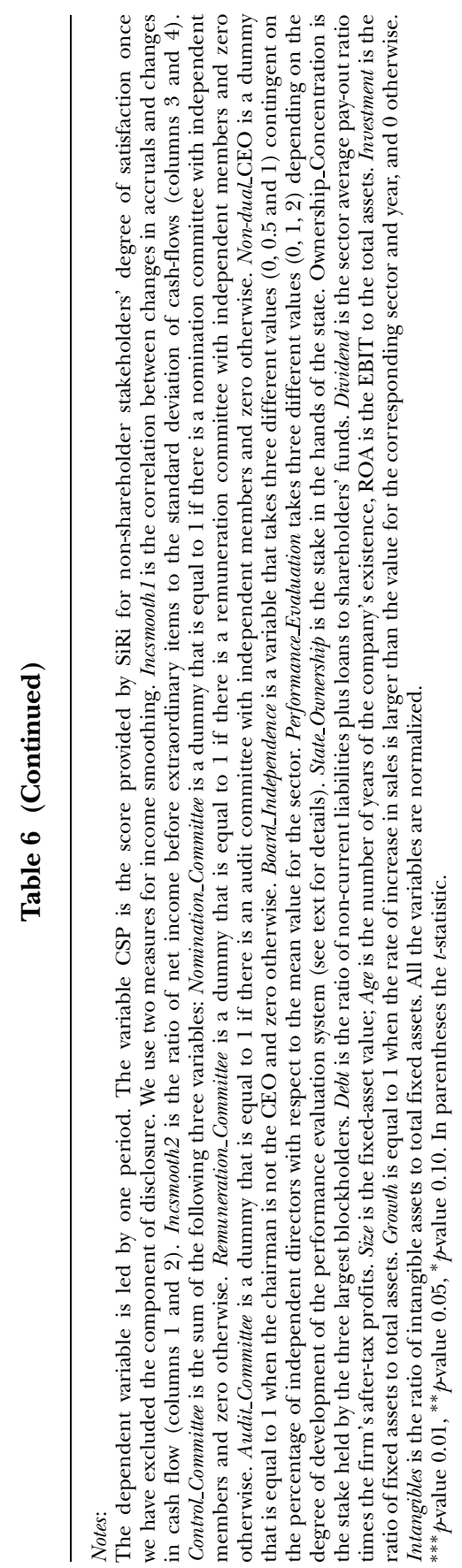


change in cash; $\triangle \mathrm{CL}$ is the change in current liabilities; $\triangle \mathrm{STD}$ is the change in debt included in current liabilities; and DEP is depreciation and amortization. The second measure (Incsmooth2) is the ratio of net income before extraordinary items to the standard deviation of cash-flows. ${ }^{22}$ In Columns 1 and 2 of Table 6 , we use the first measure; while in Columns 3 and 4, we use the second measure.

From this table, we show that income smoothing has a positive impact on CSP as well as on workers' satisfaction. It is important to stress that this is not due to the increase in the short-term financial performance due to earnings manipulation, because we have controlled by a performance variable through the ROA. Our explanation, which supports our basic theory, is that income smoothing is connected with entrenchment practices that may further stimulate improvements in CSP. ${ }^{23}$

\section{(ii) Expropriation of Minority Shareholders}

We conduct an additional analysis to investigate if the changes of CSP and in workers' satisfaction are explained in terms of other agency problems like minority expropriation, instead of entrenchment, as mentioned in the theoretical part. In the corporate governance literature (e.g., Shleifer and Vishny, 1997), the presence of blockholders (e.g., families) is contemplated to have an ambiguous effect on a firm's financial performance. On the positive side, blockholders diminish the entrenchment possibilities of managers, which impacts positively on performance; but, on the negative side, large shareholders may expropriate minority shareholders, thereby reducing the market price of shares. One strategy that blockholders may follow to expropriate minorities is the overinvestment in CSP (Barnea and Rubin, 2006). By implementing certain social programs, blockholders receive the full benefits associated with CSP, but only bear a portion of the costs to implement such policies (proportional to their stakes). This association between ownership concentration and CSP found support in some recent studies (Barnea and Rubin, 2006; and Neubaum and Zahra, 2006).

Bearing this idea in mind, it is important to distinguish improvements in CSP that are connected to the entrenchment practices from those that may be explained in terms of the implementation of expropriating strategies. We try to tackle this problem by introducing variables for ownership concentration in each specification. In Table 7, we extend this analysis and distinguish firms according to their ownership concentration (Columns 1 and 2). This is proxied by the stake of the three largest blockholders. Additionally, we distinguish between family firms - when the largest blockholder belongs to a family - and non-family ones. Authors agree that expropriation is more likely among the former firms. Finally, we compare firms where workers have substantial power (e.g., they are unionized) with their counterparts (Columns 5 and 6). We define firms with worker power as those where workers have board level responsibilities and/or

22 Unfortunately, we have no information on cash-flow statements and we estimate accruals from balance sheet changes in working capital (excluding cash). Although this introduces some bias into the estimations using the first measure (Hribar and Collins, 2002), the coincidence of the results, once we use the second measure, gives us confidence in our analysis.

23 We have conducted an alternative analysis (available upon request from the authors) where earnings manipulation is approached through the discretionary accruals obtained as the difference between the accruals and those expected from the models given by Jones (1991), Dechow et al. (1995) and Kothari et al. (2005), respectively. The results are consistent with those found using the proxies for income smoothing. 


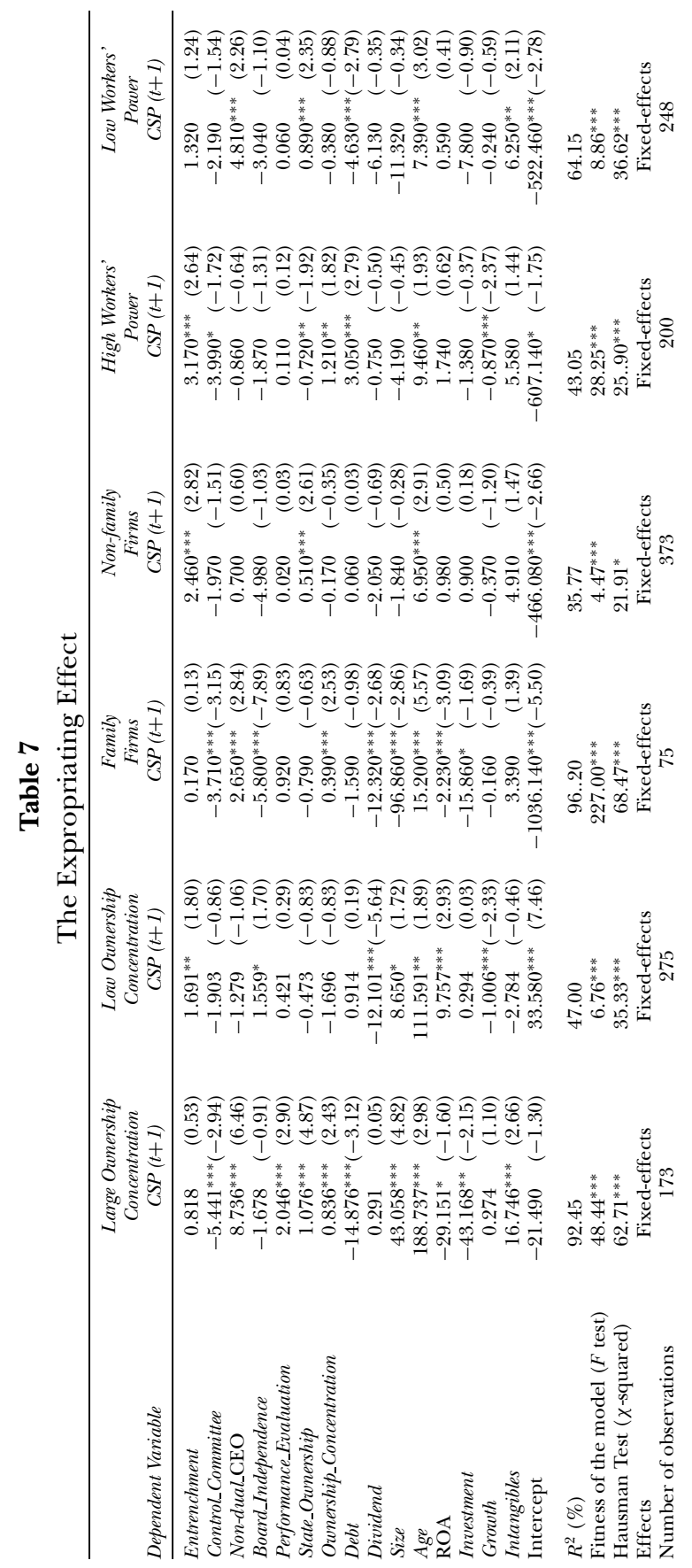




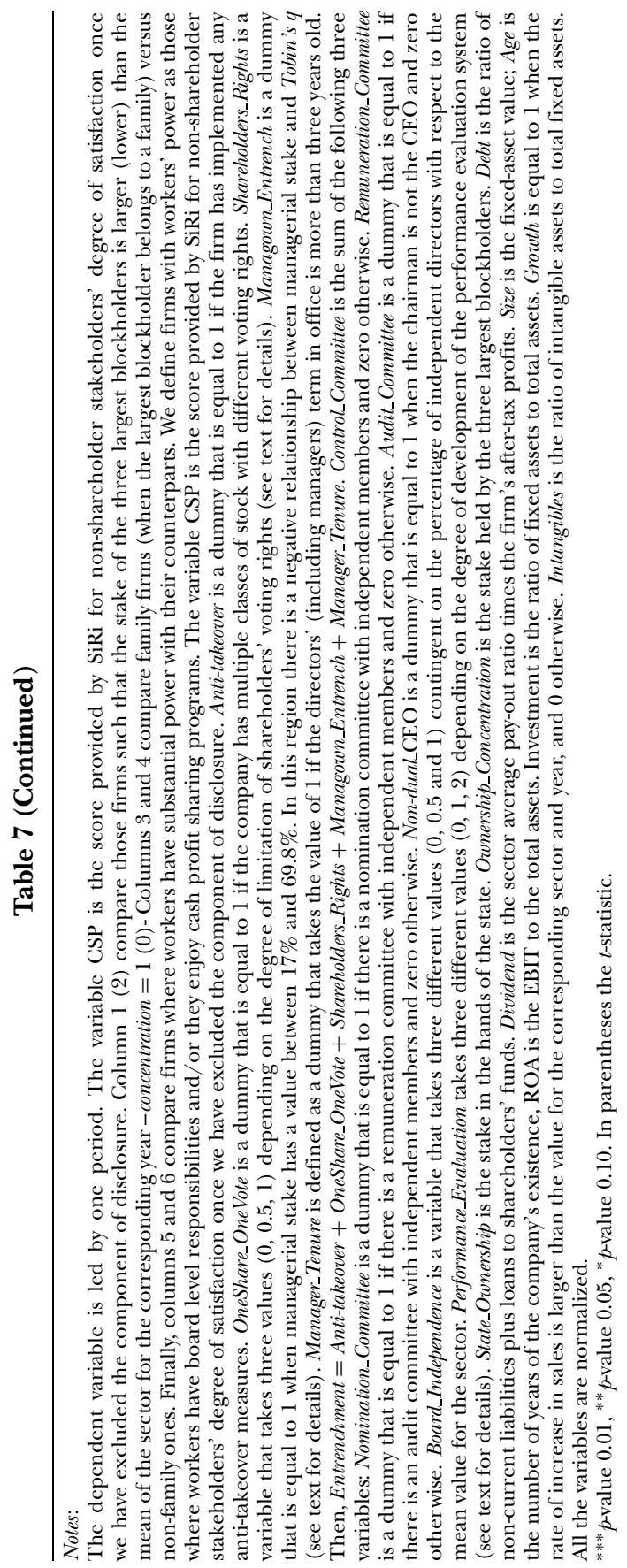


benefit from profit-sharing programs. We expect that the agency problem between large blockholders and minority ones will be less likely in firms with worker power, once we take into consideration the workers' stake in the firm.

We see from the results that the impact of our proxy of entrenchment on CSP has only positive effects in those firms where ownership is not concentrated (lower than the mean of the sector for the corresponding year), in non-family firms, and in firms with significant worker power. In these firms, we expect that there is no expropriation to minority shareholders. This ensures that the effect found on CSP is explained exclusively in terms of entrenchment and not in terms of expropriation, and gives further support to our results.

\section{(iii) Leverage, Degree of Financial Markets Efficiency, and Size}

As an additional robustness check, we conduct three additional analyses. First, we split the sample into those firms whose leverage is larger than the mean of their corresponding sector and year. The results, reported in the first two columns of Table 8, show that the effect of entrenchment on CSP is only visible for high-leverage firms. This is consistent with the idea that debt complements internal corporate governance mechanisms to control managers and limit their discretion. As such, in accordance with hypotheses 1 , we expect that the impact of entrenchment on CSP should be more significant for highly-leveraged firms.

A second analysis is performed by comparing firms whose country of origin has an Anglo-Saxon legal code, to those whose countries have a German, or French origin legal code. We have argued previously that financial markets are not fully efficient and do not fully internalize the costs of implementing costly socially responsible actions linked to entrenchment. This fact, among other things, explains the use of socially responsible actions as an entrenchment device, even in the presence of external corporate governance mechanisms. A consequence of this is that the results connecting entrenchment and CSP should be more evident in countries with less developed financial markets. As La Porta et al. (1998) show, countries with French and German origin legal codes have less developed financial markets compared with Anglo-Saxon ones. Consistently, we find that entrenchment only explains our measure for CSP in countries whose legal codes have French or German origins. Note also that countries with less developed external corporate control mechanisms are also those with more developed internal corporate control mechanisms acting as substitutes of the former (Dargenidou et al., 2007). In such cases, according to our hypothesis 1, a much stronger impact of entrenchment on CSP should be expected.

A final concern is the existence of a possible sample selection bias given that the firms in our sample are mainly large firms. In order to investigate such an issue in more detail, we split the sample into large firms (size larger than the mean of the sector for the corresponding year) and small ones. The results (Columns 5 and 6) show, as expected, that the effect is slightly more significant for large firms, but also appears for small ones. This means that size of firm may have some effects, but our results are still valid for smaller firms. This excludes problems linked to sample selection bias.

\section{CONCLUSIONS}

In this paper, we investigate the effect of the implementation of entrenchment strategies on socially responsible actions. Our basic premise is that the manager 


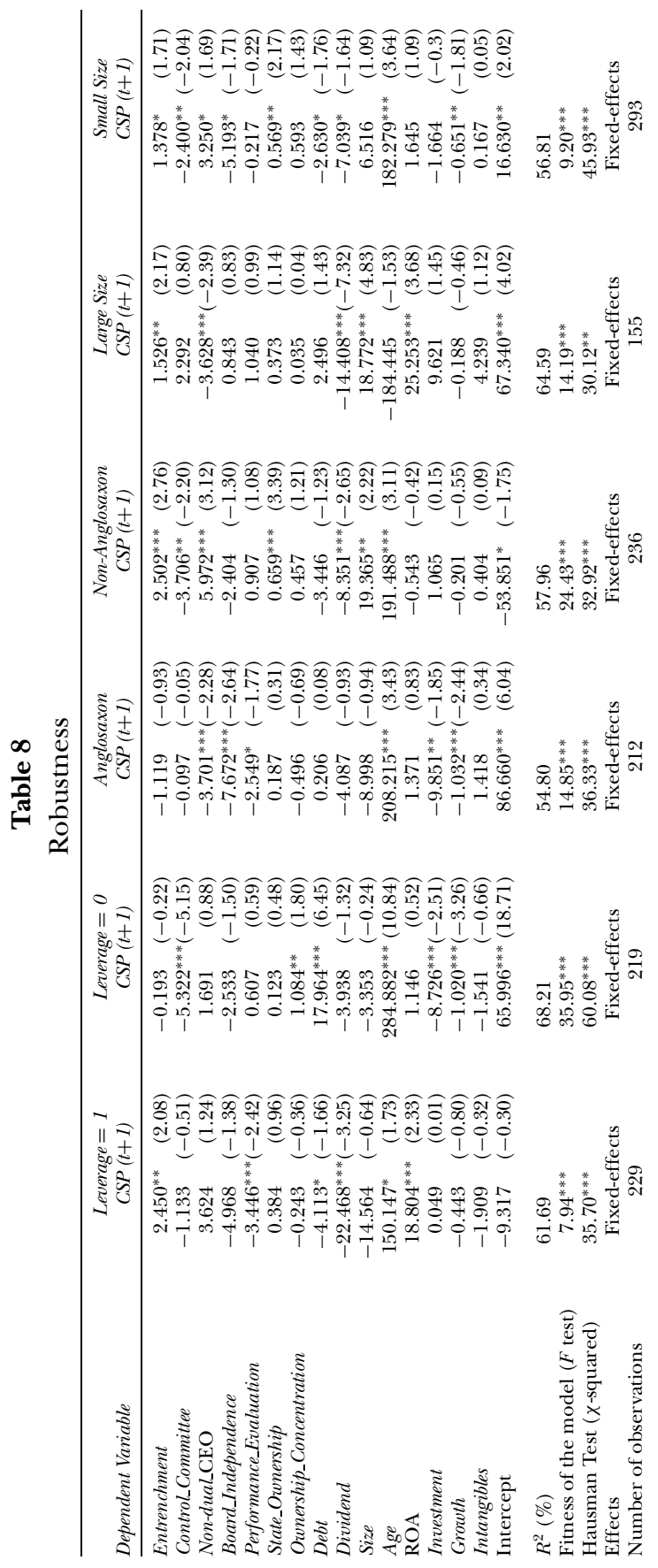




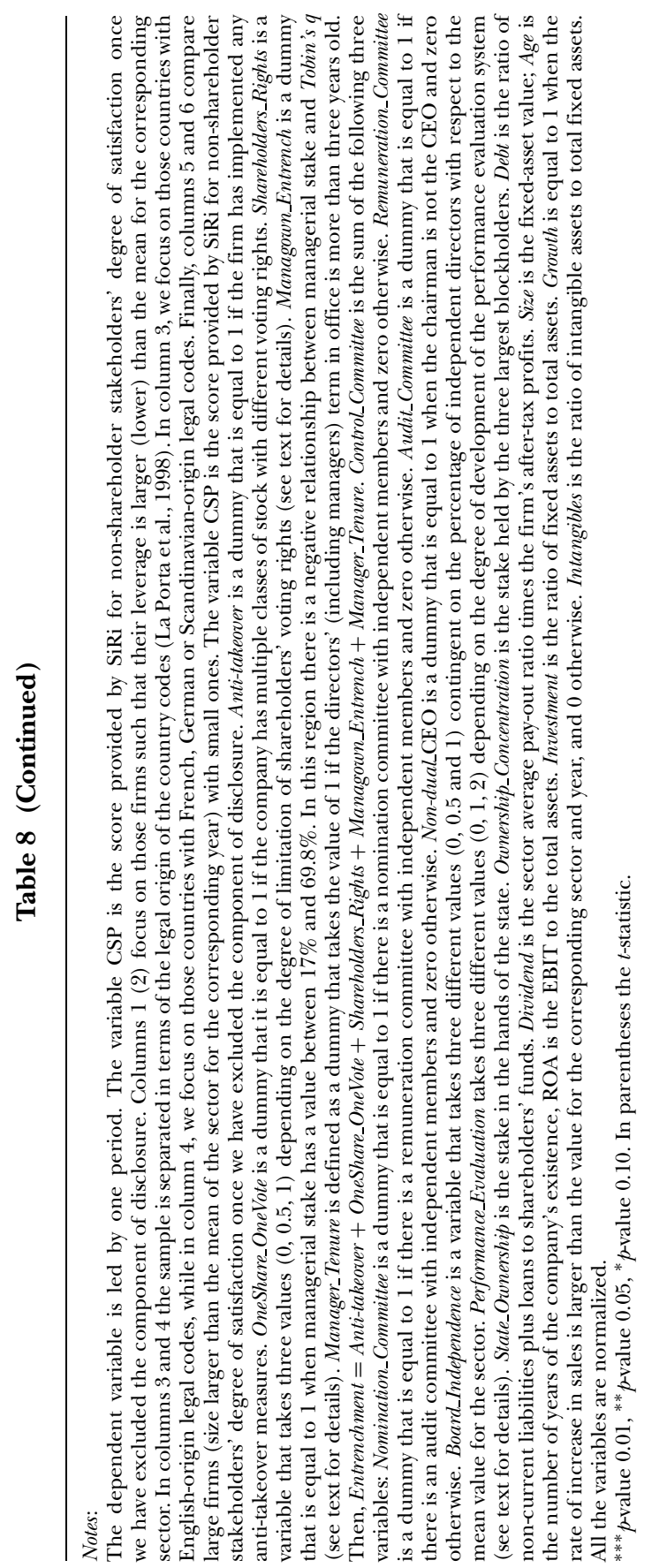


may be controlled by shareholders - externally through the financial markets and internally through the board of directors - as well as by the activism of different stakeholders. Within such a context, entrenchment strategies aimed at hindering the actions of shareholders are ineffective, unless accompanied by other measures tailored to neutralize stakeholder pressure. In this case, there are two possibilities: confrontation with stakeholders; or collusion - so as to satisfy their interests. We argue that an entrenched manager will choose the collusion strategy, especially when internal corporate governance mechanisms are well developed. In such a situation, the collusion with non-shareholder stakeholders will not only tackle the pressure from stakeholders but will, more importantly, channel the salience of these stakeholders against agents shareholders - who intend to replace the manager.

We tested this claim by looking at the connection between entrenchment and the scores for corporate social performance (CSP) as well as for worker satisfaction. We find that there is a clear positive impact of the former on the latter variables, especially in those firms with efficient internal corporate governance mechanisms like the existence of independent control committees, the separation between the CEO and the chairman of the board, and the implementation of performance evaluation schemes. This confirms the main theoretical contention of the paper: a firm's socially responsible activities may form part of a manager's entrenchment strategy.

Additionally, we prove the robustness of this contention by using an alternative proxy of entrenchment that is the implementation of earnings manipulation practices based on income smoothing (Fudenberg and Tirole, 1995). Our results are fully consistent with the theoretical claim.

The second step in our analysis consists of looking at the impact on performance brought on by an entrenchment strategy. We find that the negative impact on financial performance is more pronounced when an intensive entrenchment strategy is combined with increases in socially responsible actions. Accordingly, we argue that an intensive entrenchment policy is a reaction to the existence of stringent internal governance mechanisms. In such a situation, although entrenchment is less likely, a manager set on entrenchment combines such an aggressive strategy with the development of socially responsible activities. This combination has particularly negative effects on shareholders' wealth. This factor is further evidence that entrenched managers heed stakeholder satisfaction not only as a consequence of stakeholder activism, but also as a way of reinforcing their entrenchment strategy against shareholders.

Remarkably, our result also holds true when we focus on a stakeholder group, the workers. We argue that these stakeholders are amongst the most powerful and the entrenched manager should pay particular attention to looking after their interests.

Finally, we show that the results are more pronounced in countries with less efficient financial markets (civil law countries) and more developed internal corporate control mechanisms. In such countries, managers can take advantage of that inefficiency and over-invest in socially responsible activities in order to complement an entrenchment strategy, given that market prices do not fully reflect the cost of implementing these activities. Also, we discard other explanations linked to the implementation of expropriating policies in order to explain the increases in social performance. We also prove that increases in CSP linked to entrenchment appear in firms with low ownership concentration, particularly in non-family firms, and in firms where workers enjoy significant power. Minority expropriation is less likely in such firms; so that therefore, 
the increases in CSP are due to entrenchment and not connected to expropriating issues.

\section{(i) Implications}

This work forms a bridge between the corporate governance literature and stakeholder theory. According to this latter line of research, the management of stakeholders is a good way of improving financial results (Jones, 1995), whereas corporate governance emphasizes the difficulty in reconciling the demands of a wide set of stakeholders (Jensen, 2001; and Tirole, 2001). We show that trying to satisfy different stakeholders' interests, independently of their salience, may have adverse consequences on performance when combined with the implementation of entrenchment policies. Then, it is not good policy to give managers any leeway in determining the degree of satisfaction of non-shareholder stakeholders because managers may choose socially responsible activities strategically to complement entrenchment initiatives. Furthermore, we find that the existence of strong internal corporate governance mechanisms is not a guarantee that CSP may not be misused. In fact, the linkage between CSP and entrenchment is stronger for those firms with strong corporate governance. So how does one deal with such a problem?

There are different possibilities. First, in line with Cespa and Cestone (2007), if a firm's CSP may be used as an integral part of an entrenchment strategy, then some form of governance mechanism that hinders managerial discretion on social issues is needed. A possibility is to regulate social issues in order to avoid overinvestment in socially responsible actions. Undoubtedly, mandatory accounting practices to reflect these issues on the balance sheet may be a first step in this direction. A second way to prevent entrenchment problems, especially when involving other stakeholders, is to transfer ownership to this group. For example, if workers also have shares in a firm, it will not make sense for the manager to implement simultaneously an entrenchment strategy of confrontation with shareholders and another of collusion with other stakeholders like workers, because the interests of the latter will also be aligned with those of shareholders. Paradoxically, the interests of shareholders are better defended by transferring part of their powers to other stakeholders.

\section{(ii) Competing Hypotheses and Future Research}

Alternative theoretical arguments may compete with our entrenchment hypothesis. First, we can explain the positive connection between entrenchment and CSP by looking at normative or self-promotion motives (see Donaldson and Preston, 1995). Managers with high ethical standards would promote CSP while, at the same time, define entrenchment strategies that are geared towards the wellbeing of the firm according to themselves. Within such a framework, CSP is used normatively, not strategically, and generates the same set of results that we obtain: a positive connection with entrenchment and, when complemented with this latter variable, a negative effect on performance. In order to distinguish this hypothesis from our theoretical contention, we need to enlarge the windows of years of analysis, given that we suspect that socially friendly initiatives based on ethical grounds will be less sensitive to the economic cycle than are strategic ones. The investigation of this issue is left for future research once new sets of data become available. However, as preliminary evidence, we 
find that when we compare the results for the first year of our sample with those of the last year, the latter are more significant. This conforms to a strategic use of CSP as an entrenchment mechanism based on the fact that social awareness has been growing over time. Under a normative view, we would not observe these differences over time.

A second competing argument is that managers seek the social prestige and legitimacy of being good corporate citizens. Such managers will try to maintain their status by implementing CSP while, at the same time, entrenching their position in the firm so as to enjoy the benefits of such status. The outcome of such a combination is a negative effect on performance. This hypothesis, however, cannot explain the positive moderating role of internal corporate control mechanisms in connecting entrenchment and CSP, just as we find in our empirical analysis.

Finally, the positive association between entrenchment and socially responsible activities may be explained by the view that managers, who resort to such practices, will be able to develop longer-term relationships with stakeholders such as customers, suppliers, workers, and communities. This view will expand the set of value-creating exchanges and, therefore, generate better results. In order to ensure the longevity of such valuable relationships managers may trigger entrenchment strategies. However, this positive view of managerial entrenchment is not supported by the performance analysis conducted in this study; we find a negative impact of the combination of entrenchment and CSP on financial results.

Our work can be expanded in several directions. One research avenue consists of investigating, in greater depth, the connection between ownership structure and the entrenchment motive behind some socially responsible activities. The type of blockholder and its social sensitivity is expected to be relevant in the strategic use of CSP as an entrenchment mechanism. Finally, a further investigation on different institutional contexts may also be of interest, given the significant differences that exist in top-management orientation across countries. In Anglo-Saxon countries, managers are more inclined to satisfy shareholders' interests, while in Continental Europe and Japan, managers have traditionally been more sensitive to the development of long-term relationships with employees, banks, and suppliers. The investigation of this aspect as well as other issues is left for future research.

\section{REFERENCES}

Aguilera, R. V. and G. Jackson (2003), 'The Cross-National Diversity of Corporate Governance: Dimensions and Determinants', Academy of Management Review, Vol. 28, No. 3, pp. 447-65.

Anderson, R. C. and D. M. Reeb (2004), 'Board Composition: Balancing Family Influence in S\&P 500 Firms', Administrative Science Quarterly, Vol. 49, No. 2, pp. 209-37.

Arellano, M. and S. Bond (1991), 'Some Tests of Specification for Panel Data: Monte Carlo Evidence and an Application to Employment Equations', Review of Economic Studies, Vol. 58, pp. 277-97.

Barnea, A. and A. Rubin (2006), 'Corporate Social Responsibility as a Conflict Between Shareholders', Working Paper (EFA 2006 Zurich Meetings, Available at SSRN: http://ssrn.com/abstract=686606).

Baron, D. P. (2001), 'Private Politics, Corporate Social Responsibility, and Integrated Strategy', Journal of Economics and Management Strategy, Vol. 10, pp. 7-45.

Berman, S., A. Wicks, S. Kotha and T. Jones (1999), 'Does Stakeholder Orientation Matter? The Relationship Between Stakeholder Management Models and Firm Financial Performance', Academy of Management Journal, Vol. 42, No. 5, pp. 488-506.

Bozec, R. (2005) 'Boards of Directors, Market Discipline and Firm Performance', Journal of Business Finance Eं Accounting, Vol. 32, Nos. 9\&10, pp. 1921-60. 
Cespa, G. and G. Cestone (2007), 'Corporate Social Responsibility and Managerial Entrenchment', Journal of Economics $\mathcal{E}^{\circ}$ Management Strategy, Vol. 16, No. 3, pp. 741-71.

Conyon, M. J., S. Girma, S. Thompson and P. W. Wright (2001), 'Do Hostile Mergers Destroy Jobs?', Journal of Economic Behavior and Organization, Vol. 45, pp. 427-40.

Dahya, J., A. Lonie and D. Power (1998), 'Ownership Structure, Firm Performance and Top Executive Change: An Analysis of UK Firms', Journal of Business Finance $\mathcal{E}$ ' Accounting, Vol. 25, Nos. 9\&10, pp. 1089-118.

Dargenidou, C., S. McLeay and I. Raonic (2007), 'Ownership, Investor Protection and Earnings Expectations', Journal of Business Finance $\mathcal{E}$ Accounting, Vol. 34, Nos. 1\&2, pp. 247-68.

de Miguel, A., J. Pindado and C. de la Torre (2004), 'Ownership Structure and Firm Value: New Evidence from Spain', Strategic Management Journal, Vol. 25, No. 12, pp. 1119-207.

DeAngelo, H. and L. DeAngelo (1998), 'Ancient Redwoods and the Politics of Finance: The Hostile Takeover of the Pacific Lumber Company', Journal of Financial Economics, Vol. 47, No. 1, pp. 3-53.

Dechow, P., R. Sloan and A. Sweeney (1995), 'Detecting Earnings Management', The Accounting Review, Vol. 70, pp. 193-225.

Demsetz, H. and B. Villalonga (2001), 'Ownership Structure and Corporate Performance', Journal of Corporate Finance, Vol. 7, No. 3, pp. 209-33.

Denis, D., D. Denis and A. Sarin (1997), 'Ownership Structure and Top Executive Turnover', Journal of Financial Economics, Vol. 45, pp. 193-221.

Donaldson, T. L. and L. E. Preston (1995), 'The Stakeholder Theory of the Corporation: Concepts, Evidence, and Implications', Academy of Management Review, Vol. 20, No. 1, pp. 65-91.

Fama, E. and M. Jensen (1983), 'Separation of Ownership and Control', Journal of Law and Economics, Vol. 26, No. 2, pp. 301-25.

Farinha, J. (2003), 'Dividend Policy, Corporate Governance and the Managerial Entrenchment Hypothesis: An Empirical Analysis', Journal of Business Finance E' Accounting, Vol. 30, Nos. 9\&10, pp. 1173-209.

Feddersen, T. and T. Gilligan (2001), 'Saints and Markets: Activists and the Supply of Credence Goods', Journal of Economics and Management Strategy, Vol. 10, pp. 149-71.

Fredrickson, J. W., D. C. Hambrick and S. Baumrin (1988), 'A Model of CEO Dismissal', Academy of Management Review, Vol. 13, No. 2, pp. 255-70.

Freeman, R. E. (1984), Strategic Management: A Stakeholder Approach (Pitman: Boston, MA).

Fudenberg, D. and J. Tirole (1995), 'A Theory of Income and Dividend Smoothing Based on Incumbency Rents', Journal of Political Economy, Vol. 103, pp. 75-95.

Gompers, P. A., J. Ishii and A. Metrick (2006), 'Extreme Governance: An Analysis of Dual-class Firms in the United States' (Mimeo).

Hellwig, M. (2000), 'On the Economics and Politics of Corporate Finance and Corporate Control', in X. Vives (ed.), Corporate Governance: Theoretical and Empirical Perspectives (Cambridge University Press, Cambridge), pp. 95-136.

Hill, C. W. and T. M. Jones (1992), 'Stakeholder-Agency Theory', Journal of Management Studies, Vol. 29, pp. 131-54.

Hillman, A. J. and G. D. Keim (2001), 'Shareholder Value, Stakeholder Management, and Social Issues: What's the Bottom Line?’, Strategic Management Journal, Vol. 22, No. 2, pp. 125-39.

Hosmer, L. T. (1994), 'Strategic Planning as if Ethics Mattered', Strategic Management Journal, Vol. 15, pp. 17-34.

Hribar, P. and D. W. Collins (2002), 'Errors in Estimating Accruals: Implications for Empirical Research', Journal of Accounting Research, Vol. 40, pp. 105-34.

Jensen, M. (1986), 'Agency Costs of Free Cash-Flow, Corporate Finance and Takeovers', American Economic Review, Vol. 76, pp. 323-9.

(2001), 'Value Maximization, Stakeholder Theory, and the Corporate Objective Function', Journal of Applied Corporate Finance, Vol. 14, pp. 8-21.

and W. Meckling (1976), 'Theory of Firm: Managerial Behavior, Agency Cost and Capital Structure', Journal of Financial Economics, Vol. 3, pp. 305-60.

and R. Ruback (1983), 'The Market for Corporate Control: The Scientific Evidence', Journal of Financial Economics, Vol. 11, pp. 5-50. 
John, A. and J. Klein (2003), 'The Boycott Puzzle: Consumer Motivations for Purchase Sacrifice', Management Science, Vol. 49, No. 9, pp. 1196-209.

Jones, J. (1991), 'Earnings Management During Import Relief Investigations', Journal of Accounting Research, Vol. 29, pp. 193-228.

Jones, T. M. (1995), 'Instrumental Stakeholder Theory: A Synthesis of Ethics and Economics', Academy of Management Review, Vol. 20, No. 2, pp. 404-37.

Kothari, S. P., A. J. Leone and C. E. Wasley (2005), 'Performance Matched Discretionary Accrual Measures', Journal of Accounting and Economics, Vol. 39, pp. 163-97.

la Porta, R., F. Lopez-de-Silanes, A. Shleifer and R. Vishny (1998), 'Law and Finance', Journal of Political Economy, Vol. 106, pp. 1113-55.

Lasfer, M. A. (2006), 'The Interrelationship Between Managerial Ownership and Board Structure', Journal of Business Finance $\mathcal{E} \mathcal{F}$ Accounting, Vol. 33, Nos. 7\&8, pp. 1006-33.

Leuz, C., D. Nandab and P. D. Wysockic (2003), 'Earnings Management and Investor Protection: An International Comparison', Journal of Financial Economics, Vol. 69, pp. 50527.

Luoma, P. and J. Goodstein (1999), 'Stakeholders and Corporate Boards: Institutional Influences on Board Composition and Structure', Academy of Management Journal, Vol. 42, No. 5, pp. 553-63.

Margaritis, D. and M. Psillaki (2007), 'Capital Structure and Firm Efficiency', Journal of Business Finance Eं Accounting, Vol. 34, Nos. 9\&10, pp. 1447-69.

McWilliams, A. and D. Siegel (2001), 'Corporate Social Responsibility: A Theory of the Firm Perspective', Academy of Management Review, Vol. 26, No. 1, pp. 117-27.

Mitchell, R. K., B. R. Agle and D. J. Wood (1997), 'Toward a Theory of Stakeholder Identification and Salience: Defining the Principle of Who and What Really Counts', Academy of Management Review, Vol. 22, No. 4, pp. 853-86.

Morck, R., A. Shleifer and R. Vishny (1988), 'Managerial Ownership and Market Valuation', Journal of Financial Economics, Vol. 20, pp. 293-315.

Neubaum, D. O. and S. A. Zahra (2006), 'Institutional Ownership and Corporate Social Performance: The Moderating Effects of Investment Horizon, Activism, and Coordination', Journal of Management, Vol. 32, No. 1, pp. 108-31.

Pagano, M. and P. Volpin (2005), 'Managers, Workers, and Corporate Control', The Journal of Finance, Vol. 60, pp. 841-68.

Petersen, M. A. (2006), 'Estimating Standard Errors in Finance Panel Data Sets: Comparing Approaches' (Mimeo).

Rowley, T. and S. Berman (2000), 'A Brand New Brand of Corporate Social Performance', Business and Society, Vol. 39, No. 4, pp. 397-418.

Schneper, W. D. and M. F. Guillén (2004), 'Stakeholder Rights and Corporate Governance: A Cross-National Study of Hostile Takeovers', Administrative Science Quarterly, Vol. 49, No. 2, pp. 263-95.

Sen, P. K. (2007), 'Ownership Incentives and Management Fraud', Journal of Business Finance E Accounting, Vol. 34, Nos. 7\&8, pp. 1123-40.

Shleifer, A. and R. W. Vishny (1997), 'A Survey of Corporate Governance', The Journal of Finance, Vol. 52, No. 2, pp. 737-83.

(1986), 'Large Shareholders and Corporate Control', Journal of PoliticalEconomy, Vol. 94, No. 3, pp. 461-88.

(1989), 'Management Entrenchment: The Case of Manager-Specific Investments', Journal of Financial Economics, Vol. 25, pp. 123-40.

Stevens, J. M., H. K. Steensma, D. A. Harrison and P. L. Cochran (2005), 'Symbolic or Substantive Document? The Influence of Ethics Codes on Financial Executives' Decisions', Strategic Management Journal, Vol. 26, No. 2, pp. 181-95.

Strong, K. C., R. C. Ringer and S. A. Taylor (2001), 'The Ruled of Stakeholder Satisfaction (Timeliness, Honesty, Empathy)', Journal of Business Ethics, Vol. 32, No. 3, pp. 219-30.

Stulz, R. (1988), 'Managerial Control of Voting Rights: Financing Policies and the Market for Corporate Control', Journal of Financial Economics, Vol. 20, pp. 25-54.

Sundaramurthy, C. (2000), 'Antitakeover Provisions and Shareholder Value Implications: A Review and a Contingency Framework', Journal of Management, Vol. 26, No. 5, pp. 1005-30. 
Sundaramurthy, C., J. M. Mahoney and J. T. Mahoney (1997), 'Board Structure, Antitakeover Provisions, and Stockholder Wealth', Strategic Management Journal, Vol. 18, No. 3, pp. 23145.

Tirole, J. (2001), 'Corporate Governance', Econometrica, Vol. 69, No. 1, pp. 1-35.

Vafeas, N. (1999), 'The Nature of Board Nominating Committees and their Role in Corporate Governance', Journal of Business Finance $\mathcal{E}^{\circ}$ Accounting, Vol. 26, No. 1, pp. 199-225.

Waddock, S. A. (2004), 'Parallel Universes: Companies, Academics, and the Progress of Corporate Citizenship', Business and Society Review, Vol. 109, No. 1, pp. 5-42.

and S. B. Graves (1997), 'The Corporate Social Performance-Financial Performance Link', Strategic Management Journal, Vol. 18, No. 4, pp. 303-19.

Walsh, J. P. and J. K. Seward (1990), 'On the Efficiency of Internal and External Corporate Control Mechanisms', Academy of Management Review, Vol. 15, No. 3, pp. 421-58.

Yeo, G. H. H., P. M. S. Tan, K. W. Ho and S. Chen (2002), 'Corporate Ownership Structure and the Informativeness of Earnings', Journal of Business Finance $\mathcal{E}^{2}$ Accounting, Vol. 29, Nos. 7\&8, pp. 1023-46. 